\title{
Advances in Land Surface Modelling
}

\author{
Eleanor M. Blyth ${ }^{1}$ (D) - Vivek K. Arora ${ }^{2}$ - Douglas B. Clark ${ }^{1}$ - Simon J. Dadson ${ }^{1,3}$ • Martin G. De Kauwe ${ }^{4,5,6}$. \\ David M. Lawrence ${ }^{7}$ Joe R. Melton ${ }^{8}$. Julia Pongratz ${ }^{9,10} \cdot$ Rachael H. Turton $^{1} \cdot$ Kei Yoshimura ${ }^{11}$ • Hua Yuan ${ }^{12,13}$
}

\begin{abstract}
Land surface models have an increasing scope. Initially designed to capture the feedbacks between the land and the atmosphere as part of weather and climate prediction, they are now used as a critical tool in the urgent need to inform policy about land-use and water-use management in a world that is changing physically and economically. This paper outlines the way that models have evolved through this change of purpose and what might the future hold. It highlights the importance of distinguishing between advances in the science within the modelling components, with the advances of how to represent their interaction. This latter aspect of modelling is often overlooked but will increasingly manifest as an issue as the complexity of the system, the time and space scales of the system being modelled increase. These increases are due to technology, data availability and the urgency and range of the problems being studied.
\end{abstract}

Keywords Land surface models $\cdot$ Climate models $\cdot$ Model frameworks

\section{Introduction}

We are approaching an interesting junction with Land Surface Models (LSMs). Early models such as the BiosphereAtmosphere Transfer Scheme (BATS) [37, 38] and the Simple Biosphere Model (SIB) $[122,123]$ pioneered the use of linked soils and vegetation to describe the energy and water exchanges with the atmosphere. Since then, after decades of research, much is known about the land as a system and how to model it [109].

While originally the models were designed to capture the essential features of land-atmosphere interactions, we have learnt that provision of our food and energy also depends on these interactions between climate, soil, water and the

This article is part of the Topical Collection on Advances and Future Directions in Earth System Modelling

Eleanor M. Blyth emb@ceh.ac.uk

1 UK Centre for Ecology and Hydrology, Wallingford OX10 8BB, UK

2 Canadian Centre for Climate Modelling and Analysis, Environment and Climate Change Canada, Victoria, British Columbia, Canada

3 School of Geography and the Environment, University of Oxford, South Parks Road, Oxford OX1 3QY, UK

4 ARC Centre of Excellence for Climate Extremes, Sydney, NSW 2052, Australia

5 Climate Change Research Centre, University of New South Wales, Sydney, NSW 2052, Australia

6 Evolution \& Ecology Research Centre, University of New South Wales, Sydney, NSW 2052, Australia
Climate and Global Dynamics Laboratory, National Center for Atmospheric Research, Boulder, CO, USA

8 Climate Research Division, Environment and Climate Change Canada, Victoria, BC, Canada

9 Max Planck Institute for Meteorology, Hamburg, Germany

10 Department of Geography, Ludwig-Maximilians University Munich, Luisenstrasse 37, 80333 Munich, Germany

11 Institute of Industrial Science, The University of Tokyo, 5-1-5 Kashiwanoha, Kashiwa, Chiba 277-8574, Japan

12 Guangdong Province Key Laboratory for Climate Change and Natural Disaster Studies, School of Atmospheric Sciences, Sun Yat-sen University, Guangzhou, China

13 Southern Marine Science and Engineering Guangdong Laboratory (Zhuhai), Zhuhai, China 
vegetation. The models we have built to describe these interactions are being urgently re-cast to help us make decisions about the management of our environment to build resilience to a changing climate.

But, there is complexity both within the land-system, and how it interacts with other systems such as the atmosphere and the human system. To make progress, we need to address the challenges of heterogeneity, of complexity and of human-interaction. In their 'Perspectives' paper, [49] acknowledge the challenges of heterogeneity and complexity and propose some practical ways forward using the current LSM framework.

In this paper, we present a review of land surface modelling: its history, recent advances and issues that are limiting or inspiring a way forward, in particular to bring in the humaninteraction dimension. We focus on two important aspects to modelling:

1. Processes within a component of the land-system.

2. Exchanges between components dealing with scale mismatch and heterogeneity.

This paper aims to provide a review of how these two aspects of land surface models have evolved and how an understanding of their separate role may help us to provide a robust future for land surface modelling.

In writing this review, we worked with a selection of modelling groups from around the world to represent the various approaches to Land Surface Modelling. All of the models are part of a climate or earth system model, but some have a greater focus on land-use and carbon, while others focus more on the global water cycle. It is not possible to capture all the papers and model developments that have resulted from the massive scientific effort taking this subject forward. In the appendix, there is a table that includes the 11 of the main land surface models in current use in climate modelling. Table 1 highlights the Climate/Earth System Models with which these 11 models are associated. The shared model developments of these 11 models are summarised.

\section{Basic Concepts Used in This Paper}

The following schematic (Fig. 1) summarises the ideas presented in the paper. The processes are arranged in the horizontal from left to right representing the different timescales: roughly hourly to decadal. This highlights the huge range of timescales that the land surface models perform in. The exchanges are clearly critical in moving across this temporal range. In the vertical, the processes are working at different spatial scales and the exchange schemes are designed to deal with heterogeneity. The schematic is a generalisation of the current model structures while every model is slightly different. Figures 2 and 3 summarise the developments of the components (2) and exchanges (3) in three categories: historic (pre 2000), recent and future. A summary of the papers describing how each model treats these processes and exchanges is given in the Appendix.

In the next 5 sections, history and development of the processes and linkages are explored. They are grouped together as follows:

Section 2: Canopy Processes with Land-Atmosphere Exchange

Section 3: Snow and Soil Physics with SurfaceSubsurface Exchange

Section 4: Water Bodies with Land-Catchment and Water-People Exchanges

Section 5: Vegetation Physiology and Soil Biogeochemistry with Physics-Biogeochemistry Exchange

Section 6: Vegetation Dynamics and Land-Use with Vegetation-Landscape Exchange

We will make some conclusions in the final section (7).

\section{Surface and Canopy Processes with Land-Atmosphere Exchange}

This section addresses the physics of the exchange of momentum, water, energy and carbon between the land and the atmosphere. The processes include turbulence, evaporation and radiation transfers while the exchange critically involves techniques to accommodate the different spatial and temporal scales of the land (small spatial scale, long time scale) and atmosphere (long spatial scale, short time scale) through aggregation of the land fluxes and disaggregation of the meteorological variables. Figure 4 gives an overview of the processes discussed in this section.

Table 1 Eleven land surface models and their associated Climate/Earth System Model

\begin{tabular}{|c|c|c|c|c|c|c|c|c|c|c|c|}
\hline & CABLE & CLASSIC & CLM & CoLM & G/LM & ISBA & JSBACH & JULES & Matsiro & Orchidee & TESSEL \\
\hline C/ESM & ACCESS & CanESM5 & $\begin{array}{l}\text { CESM } \\
\text { NorESM } \\
\text { CMCC }\end{array}$ & $\begin{array}{l}\text { CAS-ESM } \\
\text { CAMS-CSM } \\
\text { BNU-ESM }\end{array}$ & $\begin{array}{l}\text { ESM2M } \\
\text { ESM2G }\end{array}$ & $\begin{array}{l}\text { CNRM-CM6 } \\
\text { CNRM-ESM }\end{array}$ & $\begin{array}{l}\text { MPI-ESM } \\
\text { ICON-ESM }\end{array}$ & UKESM & $\begin{array}{l}\text { MIROC } \\
\text { NICAM }\end{array}$ & IPSL-CM5 & EC-Earth \\
\hline
\end{tabular}


Fig. 1 Schematic of Land Surface Model showing Components (process or module) and the exchanges between components across temporal scales (hourly to decadal)

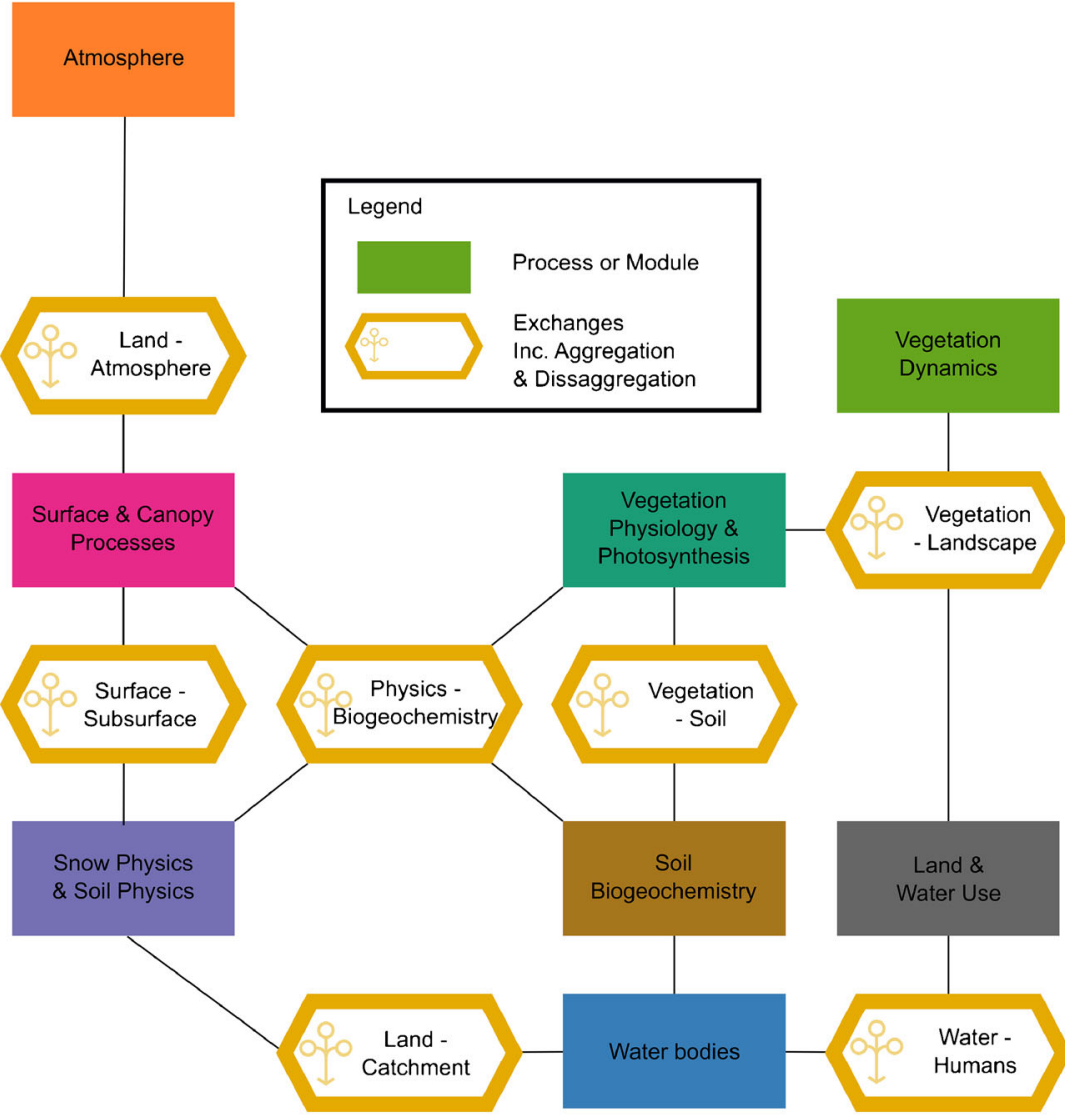

Temporal Scale

eg. Hourly

eg. Decadal

\section{History}

Momentum transfer is a fundamental part of weather forecasting and research goes back to the early 1900s (for a review see Anderson [2]). The turbulent transfer of momentum was represented using a bulk transfer equation with a roughness length that depended on the surface. In the 1970s, it became common practice to use this approach for the latent and sensible heat transfers, but with a smaller $(\times 0.1)$ roughness length. To simplify the problem, the same roughness length was used for both water and heat (and now carbon) fluxes.

Inclusion of carbon exchanges in LSMs was introduced in the 1990s. The sensitivity of photosynthesis to light levels meant that LSMs needed to represent the filtration of light through the plant canopy. The first attempts to do this used Beer's Law [123] and then an improved 'two-leaf' model which represents a sunlit and shaded canopy ([26, 36]; Y. [139]).

One of the great challenges for the land-atmosphere exchange is the contrast of the spatial and temporal scales involved. The land has a fine spatial structure with variations in land cover at scales of $100 \mathrm{~m}$, but evolves relatively slowly (weekly), while due to the mixing of the air, the atmosphere has dominant spatial scales of $10 \mathrm{~km}$ or $1 \mathrm{~km}$ for convective systems, with a temporal scale of hours or even minutes for convective systems. The exchange of key variables such as rainfall, radiation, evaporation and momentum need to accommodate these different scales. Many of the assumptions used to aggregate and disaggregate the variables are implicit and buried within the model code. It is important that we understand these assumptions and make them explicit so that when the models change their scale (for instance as we move into convective permitting models), we can continue to correctly represent these exchanges. In the following, two examples of how models accommodate these differences in scale are described.

Precipitation given by a weather or climate model is the hourly-average over a large area (up to $100 \mathrm{~km}^{2}$ ). Over this time-space, it appears to be drizzling all the time [110]. The exchange scheme needs to account for this misrepresentation of the true heterogeneous, spikey nature of precipitation. Dolman and Gregory [39] used a statistical description of 

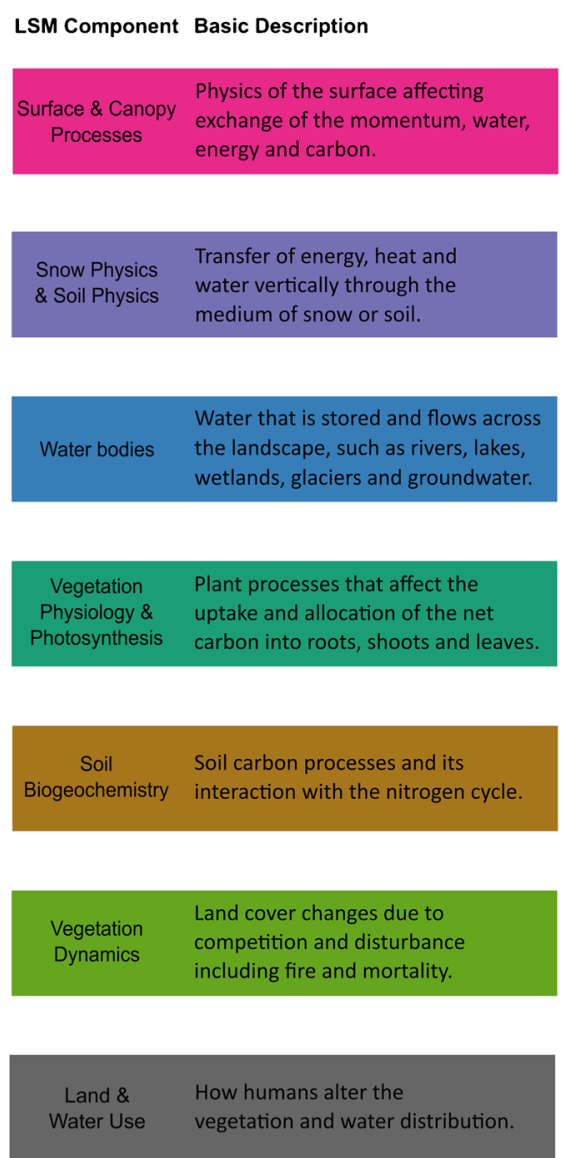

\section{Pre 2000}

Turbulent exchange of momentum, heat, water and carbon.

Beer's law for radiation attenuation through canopy.

\section{Darcy-Richards equation} Soil freezing included.

Single snow layer.

Riverflow transported to ocean with no losses.

Photosynthesis linked to

transpiration.

Phenology included.

Carbon uptake affects plant growth and LAI.

\section{Single carbon store with respiration} linked to moisture and temperature.

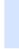

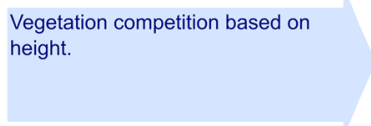

Agriculture defined as a land-cover

type
Recent Advances

Multiple canopy layers for radiation attenuation.

Deeper soil layers for Permafrost.

Organic soils included.

Multiple snow layers.

\section{Inundation, wetlands and}

groundwater.

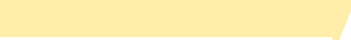

Introduce dynamic nitrogen cycle to affect photosynthesis.

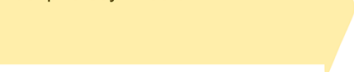

Multi-layered soil carbon.

Linked nitrogen and soil carbon.

\section{Mortality due to fire, pests and drought. \\ Age-classes of forests introduced.}

\section{Different crop-types included.}

Future Directions

Multiple canopy layers for energy, water and carbon exchanges. Microclimate within vegetation canopy.

Flows of water across the grid. Soil tiles for heterogeneity of soils.

Nutrients and water quality. Representation of hillslope-scale dynamics including interaction with river network and groundwater.

\section{Acclimation of plants to \\ temperature. \\ Response to increase of $\mathrm{CO} 2$}

More nutrients such as phosphorus Acclimation of soil carbon respiration to temperature changes.

Vegetation distribution linked landscape heterogeneity through soil tiles.

Link to other models for food and water use.

Irrigation dynamic with water need and available

Fig. 2 Land Surface Model Component development for pre 2000, recent advances and future directions

rainfall intensity distribution to counteract the drizzle effect in the JULES model [9] to improve the representation of infiltration and interception.

Up until the 1990s, each grid box had only one dominant land-cover type. The first breakthrough for representing the true heterogeneity of the land-surface came with the use of tiles, so that each land-cover occupied a fraction of the grid box with a separate energy balance equation for each. This approach was pioneered by Koster and Suarez [75] and now tiling schemes are commonly used, aided by the availability of high-resolution remote sensing datasets (1 km or finer) (e.g. $[3,45,54,61,87])$.

\section{Recent Advances}

Direct light throws hard shadows unlike diffuse light, which, coming from many angles reaches down further into a tree canopy. A recent improvement in LSMs is to replace the Beer's Law or the 'two-leaf' model with a 'multi-layer' scheme [12-14]. The impact of this on the carbon balance is notable [96]. The new 'multi-layer' models need the direct and diffuse components of incoming shortwave radiation to be quantified.
Recently, tiling schemes have been improved by using new data on ecological trait databases $[70,71]$ to increase the number of Plant Functional Types (PFTs) [62, 141]. In addition, the most advanced LSMs have included soil tiles as well as vegetation tiles $[33,48,63,114,116]$.

\section{Current Limitations and Future Directions}

While the momentum fluxes are well represented (having the advantage of a single boundary condition of zero wind speed), the science behind the transfer of heat and water is more complex. For instance, in a typical landscape, there are several surfaces with different energy budgets which vary in time (as leaves wet up and dry out, as the sun comes in and out) and space (within a canopy, below a canopy, mixtures of vegetation and soil). All these surfaces contribute to the surface temperatures which acts as the boundary condition to the atmosphere. A good summary of this issue of heterogeneity is given by Verhoef et al. [135].

Even within a canopy, there are potential improvements that can be made to represent different canopy structures and their impact on the light, temperature, momentum water and carbon exchanges. One way forward is to model the different 


\begin{tabular}{|c|c|c|c|c|}
\hline LSM Exchange & Basic Description & Pre 2000 & Recent Advances & Future Directions \\
\hline $\begin{array}{l}\text { Land - } \\
\text { Atmosphere }\end{array}$ & $\begin{array}{l}\text { Exchanges between the land } \\
\text { and the atmosphere; involves } \\
\text { aggregation of the land fluxes } \\
\text { and disaggregation of the } \\
\text { meteorological variables. }\end{array}$ & $\begin{array}{l}\text { Rainfall intensity distribution } \\
\text { accounted for. } \\
\text { Tiled representation of vegetation. }\end{array}$ & $\begin{array}{l}\text { Improved description and more tiles. } \\
\text { Direct and diffuse short-wave } \\
\text { radiation available. }\end{array}$ & $\begin{array}{l}\text { Exchange scheme is flexible to } \\
\text { match a range of model grid sizes. }\end{array}$ \\
\hline $\begin{array}{l}\text { Surface - } \\
\text { Subsurface }\end{array}$ & $\begin{array}{l}\text { Exchange of water and heat } \\
\text { between the surface and soils } \\
\text { below ground and the } \\
\text { snow-pack. }\end{array}$ & $\begin{array}{l}\text { Rainfall-runoff model assumes } \\
\text { statistical heterogeneity of soil } \\
\text { moisture. }\end{array}$ & $\begin{array}{l}\text { Rainfall-runoff model includes } \\
\text { topography and groundwater. }\end{array}$ & $\begin{array}{l}\text { Tiled soils will include explicit } \\
\text { description of soil heterogeneity. }\end{array}$ \\
\hline $\begin{array}{c}\text { Physics - } \\
\text { Biogeochemist }\end{array}$ & $\begin{array}{l}\text { Temperature and moisture } \\
\text { affect the plant and soil } \\
\text { processes. Changes in } \\
\text { structure affects the physics. }\end{array}$ & $\begin{array}{l}\text { Moisture and temperature affect } \\
\text { biological systems such as } \\
\text { photosynthesis and respiration. } \\
\text { Light levels affect photosynthesis. } \\
\text { Changes to plants structure affect } \\
\text { roughness length. }\end{array}$ & $\begin{array}{l}\text { Soil moisture and temperature at } \\
\text { deeper layers affect soil carbon. }\end{array}$ & $\begin{array}{l}\text { Distribution of leaf temperatures } \\
\text { through the canopy to affect } \\
\text { photosynthesis. } \\
\text { Roots respond to groundwater level. } \\
\text { Changes to the soil hydraulic } \\
\text { properties from changes in carbon } \\
\text { content. }\end{array}$ \\
\hline $\begin{array}{l}\text { Vegetation } \\
\text { - Soil }\end{array}$ & $\begin{array}{l}\text { The movement of carbon and } \\
\text { nitrogen between the plants } \\
\text { and soil is through leaf-litter } \\
\text { and nutrient uptake by the } \\
\text { plants. }\end{array}$ & $\begin{array}{l}\text { Carbon from leaf litter transferred to } \\
\text { soils. }\end{array}$ & $\begin{array}{l}\text { Nitrogen in the leaves transferred to } \\
\text { soils. } \\
\text { Nutrient levels in soils taken up by } \\
\text { plants. }\end{array}$ & $\begin{array}{l}\text { More information about nutrient } \\
\text { content of leaf litter. } \\
\text { Improved representation of plant } \\
\text { nutrient uptake. }\end{array}$ \\
\hline $\begin{array}{l}\text { Vegetation } \\
\text { - Landscape }\end{array}$ & $\begin{array}{l}\text { Vegetation competition and the } \\
\text { agriculture affect the land- } \\
\text { cover. }\end{array}$ & $\begin{array}{l}\text { Dynamic vegetation model informs } \\
\text { tile fractions. } \\
\text { Agriculture fraction fixed. }\end{array}$ & $\begin{array}{l}\text { More tiles used to describe age- } \\
\text { classes. }\end{array}$ & $\begin{array}{l}\text { Age classes inform forestry and } \\
\text { land-use tiles. } \\
\text { Agriculture tiles dynamic with land- } \\
\text { use and climate. } \\
\text { Better description of heterogeneity } \\
\text { to interpret land-use decisions. }\end{array}$ \\
\hline $\begin{array}{l}\text { Land - } \\
\text { Catchment }\end{array}$ & $\begin{array}{l}\text { Overland runoff flows laterally } \\
\text { over large catchments. At } \\
\text { certain hotspots, the water } \\
\text { flows back onto the land. }\end{array}$ & Water is routed to the sea. & $\begin{array}{l}\text { Inundation and irrigation can interact } \\
\text { with the energy and water cycle. }\end{array}$ & $\begin{array}{l}\text { Groundwater, river and wetland } \\
\text { systems are fully integrated with } \\
\text { modelled hillslope-scale soil } \\
\text { hydrology and with energy and } \\
\text { nutrient cycles. }\end{array}$ \\
\hline $\begin{array}{l}\text { Water - } \\
\text { Humans }\end{array}$ & $\begin{array}{l}\text { Anthropogenic control of water } \\
\text { flow to and from rivers through } \\
\text { abstractions but also transfers. }\end{array}$ & $\begin{array}{l}\text { Water from the land supplies the } \\
\text { rivers. }\end{array}$ & $\begin{array}{l}\text { Irrigation and other anthropogenic } \\
\text { water uses. }\end{array}$ & $\begin{array}{l}\text { Humans will direct changes to the } \\
\text { water abstractions, the water use } \\
\text { and transfers. }\end{array}$ \\
\hline
\end{tabular}

Fig. 3 Land Surface Model Exchange developments for pre 2000, recent advances and future directions

surfaces explicitly. For instance, Ma and Liu [89] explore the impact of an explicit representation of the canopy. There are challenges in that the turbulence throughout and below the canopy affect the microclimatic profiles of air temperature, humidity and windspeed [13, 14]. Use of the many flux-tower data that capture subdiurnal momentum, energy, water and carbon fluxes for different sun-angles, difference light-diffusiveness and different temperatures would enable us to quantify the role of canopy structure.
In addition to the increase in complexity of the component model, the exchanges between the land and atmosphere also need to be improved. The exchange needs to respond to the time and spatial scale of the atmosphere model. For instance, when using a convection permitting atmosphere model, the precipitation becomes more intense (no drizzle effect) and assumptions about the transfer of scales no longer apply. At smaller scales, the tiles may become obsolete. In its place, the heterogeneity of the water stores across the land may become more important (see Section 4).
Fig. 4 Schematic of surface and canopy processes represented in LSMs

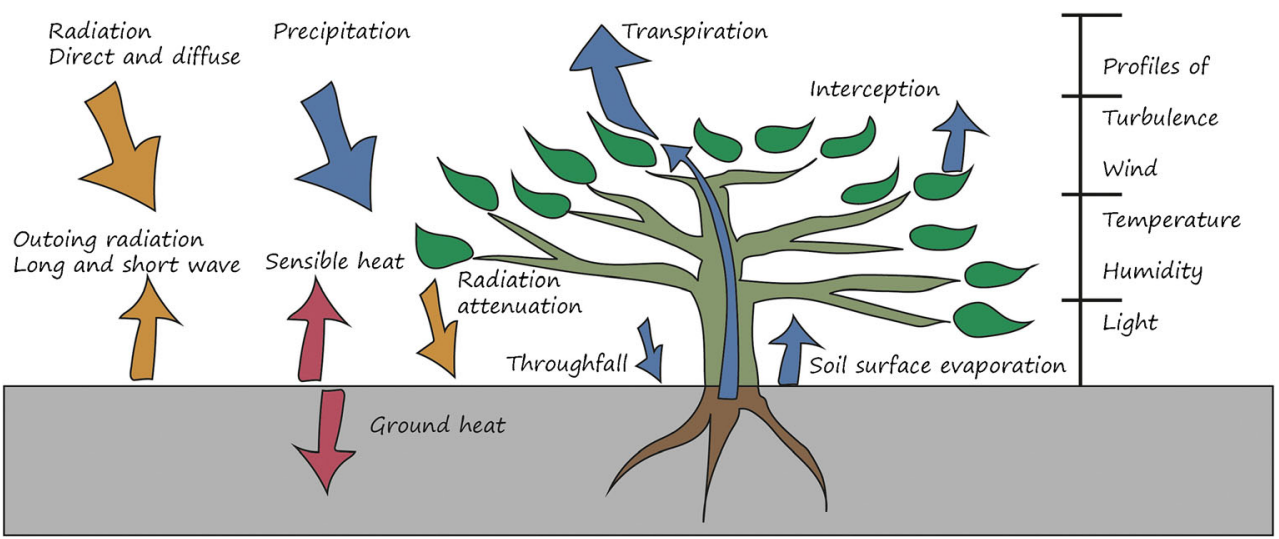


Finally, as Land Surface Models are used a finer scales and feeding policy direction for human health and wellbeing, the need for improvements to the representation of Urban landsurface is becoming more urgent. Urban areas give rise to phenomena such as 'urban islands', and are subject to more extreme flooding conditions due to the reduced infiltration capacity. The first Model Intercomparison of Urban models is just being published and shows how varied they are [57].

\section{Snow and Soil Physics with Surface-Subsurface Exchange}

This section deals with the transfer of energy, heat and water through snow or soil. Exchanges between the surface and canopy layer and the soils need to accommodate the heterogeneity of soil properties and soil-water across the landscape and with depth. Figure 5 gives an overview of the processes discussed in this section.

\section{History}

The water from precipitation has several possible fates. It might flow into the soil matrix where it will be stored before being lost through evapotranspiration or drainage. If the water remains on, or near, the soil surface it may evaporate, or if the ground is sloped or already saturated, it can contribute to runoff.

Since the early twentieth century, research has been undertaken to describe the flow of water through unsaturated soil. Combining the gravitational force and capillary force together, the flow of water in the soil can be summarised in one equation, known as the Darcy-Richards equation [117]. This equation is widely used in LSMs, although its dependence and sensitivity to the parameters of the equations mean that its usefulness is still debated [47]. The parameters for the

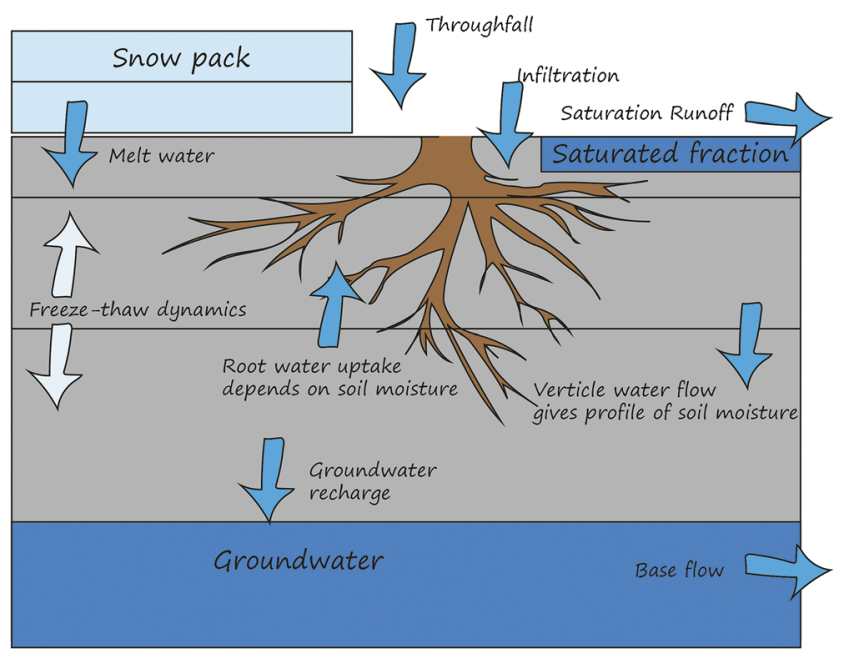

Fig. 5 Schematic of snow and soil physics representation in LSMs equations can be estimated using information about the soil textures through Pedotransfer Functions (PTFs).

Closely linked to the modelling of soil moisture is the soil temperature since the specific heat capacity of water is typically 5 times greater than the dry soil, so that a wet soil is a bigger heat-sink than dry soil (although still considerably less than the ocean). In addition, when the soil freezes, the conductivity of the soil massively reduces, eventually to zero.

A critical aspect of the soil water budget is how much water enters the soil matrix. This not only depends on the saturation of the soil, but also on soil characteristics such as texture, geomorphology and the presence of crusts. Most LSMs include a rainfall-runoff scheme which uses a statistical representation of soil-moisture heterogeneity linked to the mean soil moisture (which is used in the energy and evaporation exchanges) that were originally used by hydrologists $[11$, $84,99,132]$.

In the Boreal and Arctic regions, one of the greatest landbased impact on the atmosphere is through the snow cover. Due to its high albedo (reflecting 80 to $90 \%$ of the sunlight), snow has a strong cooling influence. Conversely, snow also acts as a thermal insulating blanket over the soil, protecting it from cold winter conditions. Model experiments using the CLM model [81] for the latter half of the twentieth century showed that variations in the amount of snow accounted for as much as $50-100 \%$ of variations in soil temperature. Many of the land surface models include a layered snow model to better capture the reflectivity at different radiation wavelengths [9].

In forested areas, the snow holding capacity of trees is limited so that much of the snow falls beneath the canopy. This results in a surface that is dark and relatively warm. Betts [10] showed that the darkening and warming impact of the presence of trees in a snowy-landscape outweighs the global-cooling effect of their carbon-absorption.

\section{Recent Advances}

As research consistently demonstrated the importance of the changes in permafrost to the evolving, warming climate, LSM developers introduced deeper soils into their models and improved the representation of organic soils. Deepening the models improved the soil thermal and hydrologic dynamics on longer timescales [80] and allowed better representation of soil carbon processes. Further model advancements attempt to account for excess ground ice [6, 82, 144], whose loss through melt creates rapid surface subsidence, altered hydrologic flow [40], and enhanced soil carbon respiration [134]. Our limited knowledge about the current amounts and distribution of excess ground ice hampers modelling efforts [103, 105].

Exchanges between the soil surface and the underlying subsurface exhibit high heterogeneity over small spatial scales. To begin to address the complexity of these exchanges, 
LSMs have adopted different strategies. Many models have added temporary sub-grid water stores such as ponding, although models that had a focus on cold-regions had it from the beginning [136].

\section{Current Limitations and Future Directions}

Soil modelling is strongly affected by the parameters which are derived from the observable soil texture using Pedotransfer Functions (PTFs). Most models use a single set of PTFs for their global modelling, but it is becoming apparent that this is not adequate and regional PTFs may be needed. It may also become important to include the way that soil properties change with time [138]. Farming practices and changes to permafrost regions will alter the soil organic matter, impacting the hydraulic properties of the soil. In addition, changes to the topography of the land as a result of changes in the permafrost conditions will need to be accommodated if we are to correctly model the hydrology and its impacts on the carbon cycle in the rapidly warming region [134].

Sub-grid heterogeneity is one of the largest limitations we have at present. For instance, Schultz et al. [121] showed that heat fluxes between different land cover types (e.g., trees and grasses) that share the same soil column can strongly impact the overall water and heat budgets. The use of soil tiles is probably the best option to deal with this. Already some models include soil-tiles to explicitly model the peat soils [77], to represent variations in maximum infiltration [35], soil textures [95] and irrigation [33].

\section{Water Bodies with Land-Catchment and Water-Human Exchange}

This section relates to the water that is stored or flows across the landscape, such as rivers, lakes, wetlands, glaciers and groundwater. The runoff from the land integrates over catchments and then occasionally or seasonally inundates the land. Meanwhile, there is an exchange between water and the human system: water can be used for industrial, agricultural and domestic use (abstractions) but water can be moved to create supply if needed (transfers). Figure 6 is a schematic of the processes discussed in this section.

\section{History}

In the past, most LSMs included rivers to link the precipitation runoff to the oceans. The first and widely used routing model that could be used globally was generated by Oki and Sud [102]. The routing mechanism was needed to estimate the timing of the flows to the sea, but no interaction with the energy or water balance of the landscape through which it flowed was included.
However, recent studies have shown that the movement of water across the land through rivers, inundation, irrigation and groundwater, under both natural and anthropogenic influence, can have a significant impact on the energy balance of the land-system. For instance, Martínez-de la Torre and MiguezMacho [90] show how the presence of groundwater can affect the energy balance of the Iberian region and Keune et al. [73] show that the inclusion of groundwater in a LSM can affect the atmospheric dynamics.

A review of how and why hydrology needs to be included in Earth System Models is covered in the review article of Clark et al. [19].

\section{Recent Advances}

New initiatives to link hydrological models to land surface models are emerging. Fan et al. [43] present a review of the need to improve the hydrology of LSMs. Some models have started to include explicit hill-slopes to represent flow across the landscape (see Appendix), some have large-scale (1000 $\mathrm{km})$ groundwater flows. Inundation and wetlands are being introduced into LSMs, for instance, Nitta et al. [101] implemented a simple snow-fed wetland scheme in an Earth System Model, which not only modelled better hydrology, but also improved the representation of land-atmosphere coupling strength.

Groundwater is a major water resource worldwide, and new attempts to include it in LSMs have been made. Fan et al. [44], de Graaf et al. [28-30], Maxwell and Condon [91] and Miura and Yoshimura [98] have all implemented new groundwater models to LSMs that can be used for assessing global future water resources.

Human intervention in the water cycle affects many aspects of the land-system. For instance, irrigation can substantially affect the energy budget of a region and several LSMs have implemented unlimited irrigation through a simple scheme in which irrigation is triggered when soil water drops below a critical threshold [120]. With this class of irrigation implementation, one can research how enhanced evaporation due to irrigation affects local and regional weather and climate (see [133]). A more complete picture of human intervention is provided by models that represent processes including water withdrawal from surface and groundwater sources, and reservoir operation (e.g. [151]). This then allows us to study the global distribution of food production and world-wide food/water/energy securities through specification of irrigation water sources [60].

Wetland soil physics and biogeochemical cycles (Section 5) are linked as saturated conditions slow the decomposition of organic matter in wetlands, leading to increased soil carbon, reduced hydraulic conductivity, and a substantial increase in the emission of methane [74, 94, 147]. Modelling of the wetland extent is key to the modelling of the methane 
Fig. 6 Schematic of the representation of water bodies in LSMs

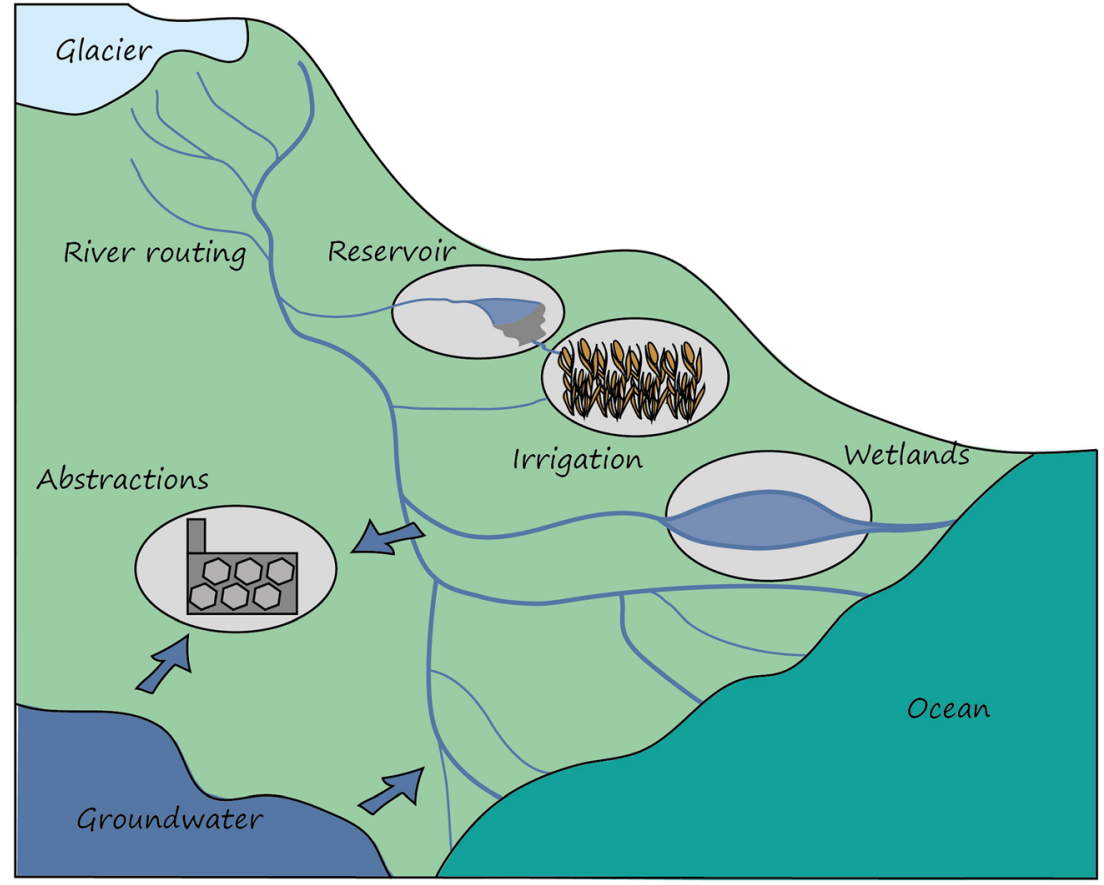

emission estimates, especially as the hydrology of these regions may change in a future climate [22]. Recent years have seen advances in the level of integration between inundation and river models with both soil hydrology and biogeochemical cycles. For example, Guimberteau et al. [58] describe an improved representation of floodplain dynamics and wetlands that is fully integrated into the modelled hydrological cycle and extended to look at riverine $\mathrm{C}$ transport. There have also been developments aimed at representing river-groundwater interactions, with reinfiltration of river water being required to reproduce observed soil moisture patterns across a catchment [153].

\section{Current Limitations and Future Directions}

While hydrological models for catchment and even smaller scales are widely used, it is only relatively recently that attempts have been made to incorporate such detailed process understanding into land surface models. The need for LSMs to capture how the flow and storage of water across a landscape is regulated by fine-scale topographic features is identified by [43]. Possible new approaches include the use of hydrological response units, and a representation of the interaction between groundwater and rivers. Although some models now include a hydrological representation of wetlands and intermittent flooding, there is still a need to better describe the effects of these on energy and nutrient cycles. A major challenge for the development of global-scale groundwater models is the difficulty in sourcing data with which to describe subsurface characteristics.
Seasonal changes in land ice and glaciers are responsible for significant changes in the river flows of many high-latitude and high-altitude basins. Current land surface models include the effects of snow and land ice on terrestrial albedo and surface energy balance, but the contribution to river flow from glacier runoff is missing and the impact on the temperature of the river-water, which may be important to the ecological community. If we want to use the land surface models to address issues of water resources, it is important to include how these quantities will respond to anthropogenic global warming [68] as it is likely that the glaciers will disappear from many areas in the next 50 years.

Many aspects of land use and land management, including the use of agricultural fertilizers, have important consequences for water quality and ecology [18], and these will need to be included in models. From an Earth System perspective, these riverine nutrient fluxes are important inputs to estuaries and shelf seas, and the interface between land and marine models will need to be developed accordingly.

The extent of anthropogenic interventions in the water cycle in many locations now places human water use at the same order of magnitude as many of the natural fluxes in the water cycle $[25,56]$. It is important that these fluxes are represented in land-surface models [24] so that future changes in water availability can be addressed. Although some models already include detailed descriptions of water management activities these often rely on the prescription of simple operating rules; future developments will need to better represent the optimal management of complex catchments and consider the economics of water use. 


\section{Vegetation Physiology and Soil Biogeochemistry and Exchanges with Physics}

There are two primary purposes of modelling vegetation physiology and soil biogeochemistry in LSMs. First, the physical structure of vegetation and the process of photosynthesis affect the exchange of momentum, energy, water and $\mathrm{CO} 2$ at the land-atmosphere boundary (Section 2). Second, the vegetation and soil processes affect allocation of the Earth's carbon to storage in the land (and oceans) compared to the atmosphere over seasonal and longer time scales. This section summarises the how the processes that govern these physical and biogeochemical interactions are modelled. Figure 7 gives an overview of the essential processes included in LSMs.

\section{History}

The process of leaf photosynthesis is well understood and most LSMs simulate photosynthesis based on theoretical models of C3 and C4 photosynthetic pathways [20, 46]. Transfer of $\mathrm{CO} 2$ into the plants through photosynthesis is inevitably linked with loss of water via leaf stomata. This coupling between photosynthesis and stomatal resistance is modelled via empirical relationships [7, 14, 20, 69, 83, 93].

All plant components including roots, shoots and leaves respire $\mathrm{CO} 2$ (referred to as the autotrophic respiration) [128]. The difference of the two large fluxes of photosynthesis (GPP) and autotrophic respiration is the net carbon gained by plants (Net Primary Production, NPP) that is allocated between the different plant components [53]. Dynamic allocation of carbon to leaves together with leaf loss associated with cold temperatures, reduced day length, and drought allow LSMs to simulate leaf phenology as a function of environmental conditions $[4,111]$. The leaf phenology responds more strongly to temperature in temperate and high-latitude regions [145] and to soil moisture in tropical regions [51]. The seasonal cycle of leaves modulates the land-atmosphere energy, water and $\mathrm{CO} 2$ fluxes [108].

There is a transfer of carbon from the vegetation to the soil through leaf fall, turnover of shoots and roots, eventual mortality of plants. The soil carbon dynamics is often modelled using multiple pools with different turnover times [131] and affected by temperature and moisture.

These dynamical carbon processes were introduced into the LSMs in the early 2000s as the modelling centres started to focus on the response of climate to the carbon cycle.

\section{Recent Advances}

Understanding the link between photosynthesis and transpiration (Water Use Efficiency) is a priority for LSMs response to climate. New approaches have been explored recently. For instance, a new optimisation theory [93] has been included in some LSMs $[31,78,104]$ which recognises that the plants will be aiming to minimise their water loss while maximising their carbon uptake. In addition, a model that accounts for how stomatal conductance respond to root zone soil moisture through explicitly modelling the cost of the hydraulic lift of the water has been developed [127, 150], although these have yet to be fully explored in LSMs (but see [119]).

Another recent advance in LSMs is to model nutrient (Nitrogen, $\mathrm{N}$ and Phosphorus, $\mathrm{P}$ ) limitations on photosynthesis $[140,152] . \mathrm{N}$ cycle modules in LSMs are also able to model emissions of $\mathrm{N}_{2} \mathrm{O}$ which is a greenhouse gas [152]. LSMs are also now including emissions of the greenhouse gas methane $\left(\mathrm{CH}_{4}\right)$ associated with natural wetlands and permafrost thaw [5, 118] (see Section 4). Anthropogenic methane emissions from
Fig. 7 A schematic of the biogeochemistry represented in LSMs

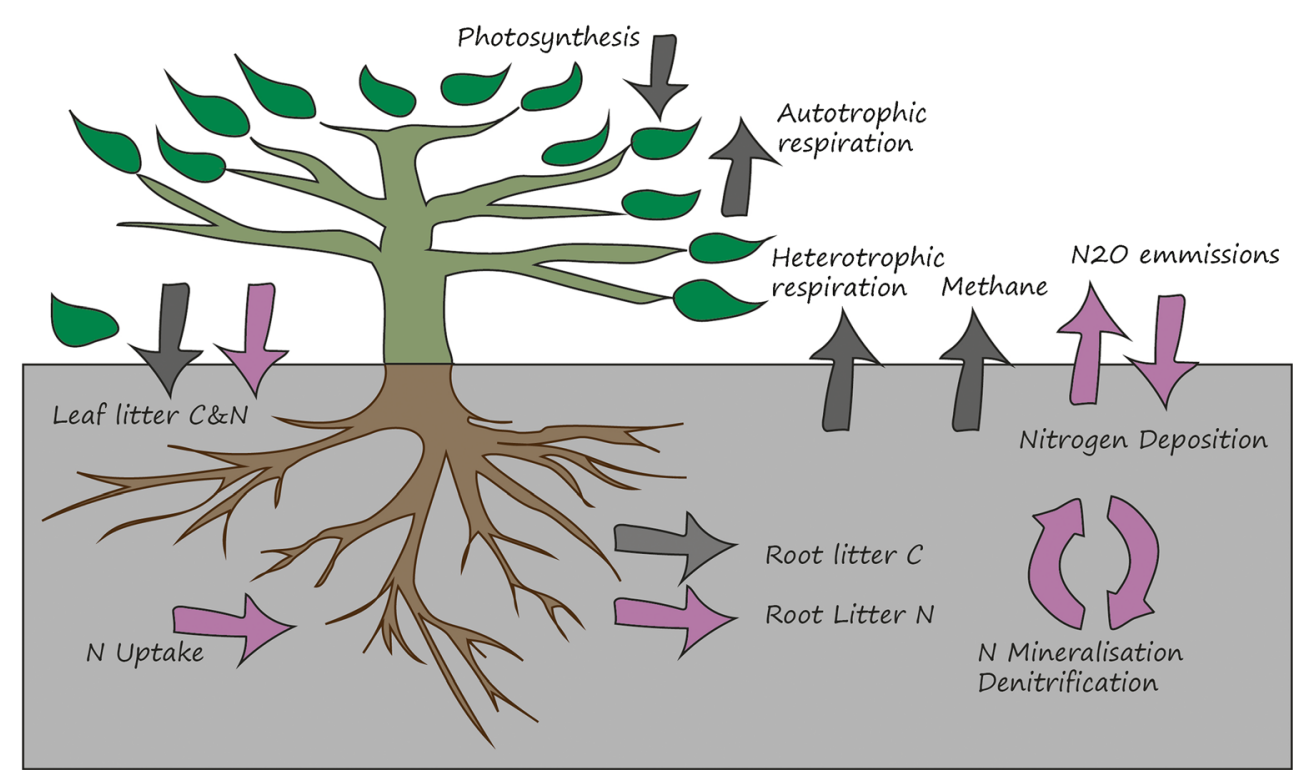


paddy rice and those from ruminants are represented in some offline vegetation models (e.g. [76]).

\section{Current Limitations and Future Directions}

The temperature response of photosynthesis is a key uncertainty in LSMs, especially the acclimation to slow temperature changes. Most models use instantaneous temperature responses, even in response to sustained warming which do not appropriately account for geographical variations (adaption) or acclimation to ambient temperature [72]. LSMs that do account for photosynthetic temperature acclimation, however, find a large influence on terrestrial carbon storage with a warmer climate $[85,97,126]$.

But, new theories that relate the essential evolutionary nature of biology are emerging which might well bring new insights into the interplay of vegetation and climate [52].

The modelling of the nitrogen cycle has been shown to be critical to understand the earth-system response to climate change. But, there is a strong anthropogenic influence that is hard to incorporate. The application of fertilizers for agriculture is an area that needs to be addressed (see Section 6).

The typical turnover rate of microbes in soil $\left(0.05\right.$ day $^{-1}$; [59]) implies their half-life is of the order of 15 days. Yet, soil carbon has one of the longest turnover time scales in the terrestrial carbon cycle $(\sim 30-50$ years or up to 1000 s of years in high latitudes) since decomposing organic matter is a slow and energy intensive process. This has led LSMs to model heterotrophic respiration as a function of environmental conditions (including aerobic and anaerobic conditions), and soil carbon mass, ignoring the direct role of microbes. New studies suggest the interactions between microbes and heterotrophic respiration are complex given the large diversity of microbes and their function $[59,137]$ and suggest that temperature sensitivity of microbial turnover may even promote soil $\mathrm{C}$ accumulation with warming, in contrast to reduced soil $\mathrm{C}$ as is predicted by traditional biogeochemical models. Wieder et al. [146] summarise how LSMs may include microbial-explicit model formulations. Modelling microbial community explicitly in LSMs is the first step toward this new functionality.

As soil-tiles are adopted (see Section 3) and canopy processes better modelled (see Section 2), then biogeochemistry can take advantage of more accurate soil moisture, temperatures, and vegetation physiology can take advantage of the range of canopy temperatures.

\section{Vegetation Dynamics and Land-Use with Vegetation-Landscape Exchanges}

Changes in the vegetation distribution affect the exchange of the land to the atmosphere through changes in the fluxes of energy, water and carbon. Vegetation distribution is altered by both anthropogenic (agriculture, deforestation) and natural dynamics (stress, fire, insect outbreaks, or windthrow).

This section describes how the LSMs include these land cover changes. Figure 8 is an overview of the processes included in LSMs.

\section{History}

The impacts of land-use change on climate were originally assessed by imposing large-scale land cover change (e.g. [66]). This approach was used in CMIP5, where the models were provided with historical and projected land-use forcing (e.g. [16]). Natural vegetation dynamics, which were developed in stand-alone models ('dynamic global vegetation models', DGVMs) [23, 125] were introduced into Earth System Models (ESMs) in some of the LSMs used in CMIP5 [17, 21, 142].

Land-use related fluxes of carbon currently contribute about $14 \%$ of annual $\mathrm{CO} 2$ emissions [55] or about one quarter of emissions when other greenhouse gases such as methane (CH4) and nitrous oxide (N2O) are included (IPCC SRCCL). This biogeochemical effect is the dominant impact of land-use on climate. A smaller effect relates to the physical effect such as the cooling of irrigated areas and the darkness of trees compared to crops and grass (see Section 2). This is called the biogeophysical effects $[10,113]$. In some places and at a local scale, local temperature changes due to biogeophysical changes can be as large as the biogeochemical effect on warming [32, 129, 148].

The overall observed trend in natural vegetation is a greening trend (with a recent evidence of a browning trend in some regions). LSMs explain these trends as a response to the physiological effects of rising $\mathrm{CO} 2$ concentration and a warming climate favouring plant growth in cold regions [149].

\section{Recent Advances}

Representations of land use and natural vegetation dynamics have been evolving rapidly. To better capture the full range of impacts of land use on the earth system, several LSMs have begun to represent agricultural practices in more detail, including specific crop parameterizations for the world's major crops along with representations of crop management practices such as planting, harvesting, irrigation and fertilization (e.g. $[15,86])$. In individual models, impacts from processes such as till/no-till practices have been examined by altering parameters for soil respiration (e.g. [115]) or adjusting soil albedos to account for soil turnover due to tillage [27]. Irrigation has been implemented by adding water to eliminate plant water stress [34], also see Section 4.

Due to the rapid development of land use models, there is a wide range of the level of comprehensiveness and the specific process implementations which confounds multi-model 
Fig. 8 A schematic of land-use and dynamical vegetation processes represented in LSMs

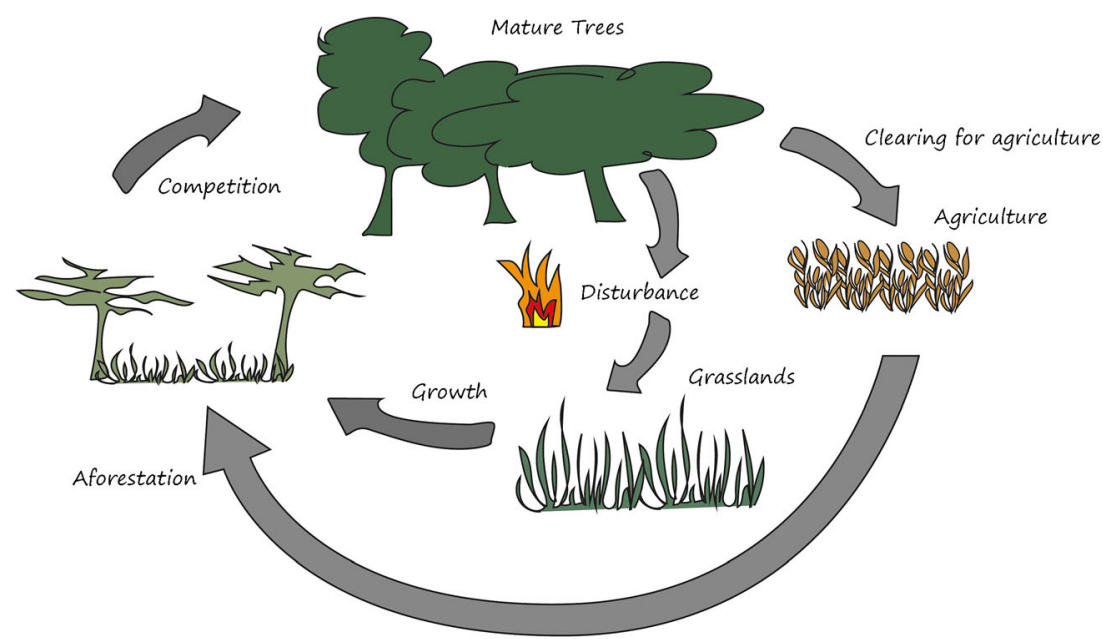

assessments of the impacts of historic and projected land-use change. In recognition of this divergence, the Land Use Model Intercomparison Project [118](LUMIP) [79] includes a large factorial set of land-only-perturbations coupled to the atmosphere models. These experiments focused in on a range of important land use processes so as to enable multi-model assessment of the impacts of specific processes on the landatmosphere exchanges.

A key to accurate simulation of the role of vegetation on the atmosphere is a representation of forest age. This enables the modelling of harvesting of specifically aged or sized trees which is needed for a detailed forestry representation (e.g. [8]). Some models represent sub-grid forest age structures inherently, while many depict only an average tree or plant age. These latter, simpler LSMs can represent the distribution explicitly with a tile for each age classes (e.g. [100, 124]). An alternative approach is to model the relationship between the distribution of the age-class and the average growth (e.g. [65]). These new generation models rely on 'cohorts', wherein plants with similar properties (age, size, age, functional type) are grouped together ([64, 67, 143]; and see [50] for a review).

\section{Limitation and Future Directions}

A recent review of the changes in land-use under anthropogenic influences is given in Pongratz et al. [112]. Among others, they show that there is now an understanding that land management can be as impactful on climate as land-cover change $[41,42,88]$ but they are un- or under-represented in present day LSMs.

Current LSMs typically represent crop phenology with relatively few phenological stages, but by doing so miss out on potential impacts of heat or water stress during key stages of the crop life cycle [106]. Further, crop modules within LSMs consider only a few of the many crop management practices in use today (i.e. mainly irrigation and fertilization). McDermid et al. [92] gives a review of including agriculture in Earth System Models.

But, many other crop management practices affect food production, agricultural land sustainability and the impact of agriculture on climate. These include cropland harvest, irrigation (discussed in Section 4), and fertilization (Section 5), forest harvest, tree species selection, grazing and mowing harvest, crop species selection, artificial wetland drainage, pest management, tillage, fire management and crop residue management.

Pongratz et al. [112] point out that for each process, there is often a basic implementation and a comprehensive implementation. To achieve a comprehensive implementation requires overcoming challenges of data limitations, and in some cases inadequate process understanding or inadequate knowledge or ability to simplify and capture specific human behaviours (e.g. farmer decisions on when to plant crops). Peng et al. [107] argue that a much more deliberate and intensive effort to merge agroeconomic crop models and land-surface models is required to provide a 'multiscale crop modelling framework [that] will enable gene-to-farm design of resilient and sustainable crop production systems under a changing climate at regional-to-global scales'.

Capturing the impacts of agricultural management on soils is a priority and requires improved representation of plantsoil-microbial interactions (as discussed in Section 5) and the impacts of agricultural management on these interactions, such as the long-term impacts of agricultural management (including pastureland and rangeland management) on soil degradation and/or loss [138]. More realistic treatment of changes in soil health would allow, for example, for study of the potential impacts of agricultural practices on flood risk.

One of the critical problems is how to specify the role of humans in the Earth System. A potential way forward is to link the ESMs with Integrated Assessment Models to ESMs $[1,130]$, thus capturing feedbacks between climate, food, water and land-use. 
The representation of vegetation dynamics is also evolving substantially, with first-generation DGVMs being replaced by demographic models based on a more realistic ecological understanding of the land system [50]. Next-generation demographic vegetation models include processes thought to be critical for ecosystem function and composition, including canopy gap formation, vertical light competition, competitive exclusion and successional recovery from natural or anthropogenic disturbance. They will also need to be responsive to the below-ground state such as soil depth, moisture and temperatures.

\section{Conclusions}

Land surface models need to balance two opposing requirements. They need to be complex enough to capture important processes and drivers of change in the real world, and parsimonious enough to be able to simulate and study a multitude of possible other worlds (new climates, new land and water uses and new locations).

One way to obtain this balance is to articulate the difference between the representation of processes within a component and the representation of the exchanges between the components. The former is critical to capture the response of ecosystems to changing climate conditions and is essentially a scientific problem. The latter is required to represent the heterogeneity of the land-system both in time and space and is essentially a modelling problem but requires scientific insight.

This review showed many examples of both these two aspects, across the 5 main modelling domains: surface and canopy exchanges, soil and snow physics, water bodies, biogeochemistry and plant physiology and vegetation dynamics. We showed how progress in one aspect may be independent (new models of stomata can be introduced without reference to other parts of the model) while others may need changes to the exchanges between components to make progress (for instance, if dynamic vegetation models need to link to sub-grid features such as soils, topography, wind stress and snow depth).

Separating out the two aspects (processes and exchanges) and making progress in both enables us to identify our priorities for delivering a model that includes both the complexity of the real world, while maintaining an appropriate level of parsimony. For instance, only components that affect the outcome of the problem being addressed need to be linked in a model configuration. Another example is that time and space scale of the application can dictate the appropriate exchanges used without affecting the representation of the components.

The future of Land Surface Modelling by the large modelling centres will probably focus on the framework for coupling components together, depending on the application. As well as the coupling across time and space scales, the framework will include the external boundary conditions and evaluation of the outputs for different applications. This will enable a marketplace for the provision of the component model which can be provided by external, academic and international researchers. Such a relationship between the central operationsfocussed modelling centres and the academic sector will service one of the un-spoken but critical aspects of land-surface modelling which is the support it provides for research and intellectual enquiry.

Ultimately, the goal is that future land surface models can address key societal and scientific questions related to ecosystem resilience under a range of environmental and anthropogenic pressures. By understanding and enabling independent development of the basic building blocks of the models and how they are combined, we can ensure a healthy future of the integrity of the science of Land Surface Modelling.

\section{Appendix A. List of widely used models and their developments with references.}

A ' $\mathrm{Y}$ ' or a paper-reference indicates the process is included in the model (although not necessarily in the operational or default version of the model), a ' $\mathrm{N}$ ' indicates it is not included in the model, and blank spaces indicate no information.

The models are as follows:

CABLE: Community Atmosphere-Biosphere Land Exchange model (Australia)

CLASSIC: Canadian LAnd Surface Scheme Including biogeochemical Cycles (Canada)

CLM: Community Land Model (USA)

CoLM: Common Land Model (China)

G/LM: Global Land Model (USA)

ISBA: Interaction Sol-Biosphère-Atmosphère (France)

JSBACH: Jena Scheme for Biosphere-Atmosphere Coupling in Hamburg (Germany)

JULES: Joint UK Land Environment Simulator (UK)

Matsiro: Minimal Advanced Treatments of Surface Integration and Runoff (Japan)

Orchidee: Organising Carbon and Hydrology in Dynamic Ecosystems (France)

TESSEL: Tiled ECMWF Scheme for Surface Exchanges of Land (Europe). 
Table 2 Land atmosphere exchange

CABLE CLASSIC CLM CoLM G/LM ISBA JSBACH JULES Matsiro Orchidee TESSEL

\begin{tabular}{|c|c|c|c|c|c|c|c|c|c|c|c|}
\hline $\begin{array}{l}\text { Tile } \\
\text { representation of vegetation }\end{array}$ & $\mathrm{Ca} 4$ & CL9 & CM12 & $\begin{array}{l}\mathrm{CO} 2 \\
\mathrm{CO} 5\end{array}$ & $\begin{array}{l}\text { LM1 } \\
\text { LM4 } \\
\text { LM6 } \\
\text { LM7 } \\
\text { LM9 } \\
\text { LM10 }\end{array}$ & $\begin{array}{l}\text { IS9 } \\
\text { IS14 }\end{array}$ & JS2 & $\begin{array}{l}\text { JU5, } \\
\text { JU8, } \\
\text { JU13 }\end{array}$ & $\begin{array}{l}\text { MA1 } \\
\text { MA2 } \\
\text { MA3 } \\
\text { MA4 } \\
\text { MA12 }\end{array}$ & $\mathrm{Y}$ & $\mathrm{T} 3 \mathrm{~T} 11$ \\
\hline $\begin{array}{l}\text { Separate } \\
\text { energy budget for } \\
\text { components } \\
\text { within a tile }\end{array}$ & $\begin{array}{l}\mathrm{Ca} 5 \\
\mathrm{Ca} 8 \\
\mathrm{Ca} 6 \\
\mathrm{Ca} 7\end{array}$ & CL13 & CM18 & $\mathrm{CO} 2$ & LM5 & $\begin{array}{l}\text { IS3 } \\
\text { IS7 } \\
\text { IS9 } \\
\text { IS12 } \\
\text { IS13 }\end{array}$ & JS3 & $\mathrm{N}$ & $\begin{array}{l}\text { MA1 } \\
\text { MA2 } \\
\text { MA3 } \\
\text { MA4 } \\
\text { MA1 }\end{array}$ & $\mathrm{N}$ & $\mathrm{T} 3 \mathrm{~T} 11$ \\
\hline Vertical layers for radiation in the canopy & $\mathrm{N}$ & $\mathrm{N}$ & CM1 & $\mathrm{CO} 10$ & $\mathrm{Y}$ & $\begin{array}{l}\text { IS8 } \\
\text { IS11 }\end{array}$ & $\mathrm{N}$ & JU6 & $\mathrm{N}$ & $\mathrm{Y}$ & $\mathrm{T} 8$ \\
\hline $\begin{array}{l}\text { Vertical layers for water and heat in the } \\
\text { canopy }\end{array}$ & $\mathrm{N}$ & CL14 & CM1 & $\mathrm{N}$ & $\mathrm{Y}$ & $\begin{array}{l}\text { IS2 } \\
\text { IS5 } \\
\text { IS11 } \\
\text { IS14 }\end{array}$ & $\mathrm{N}$ & $\mathrm{N}$ & $\mathrm{N}$ & $\begin{array}{l}\mathrm{N} \\
\text { OR3 }\end{array}$ & $\mathrm{N}$ \\
\hline
\end{tabular}

Table 3 Soil physics

\begin{tabular}{|c|c|c|c|c|c|c|c|c|c|c|c|}
\hline & CABLE & CLASSIC & CLM & CoLM & $\mathrm{G} / \mathrm{LM}$ & ISBA & JSBACH & JULES & Matsiro & Orchidee & TESSEL \\
\hline $\begin{array}{l}\text { Darcy- } \\
\text { Richards }\end{array}$ & $\mathrm{Ca} 5$ & CL14 & $\mathrm{Y}$ & $\mathrm{N}$ & LM1 LM5 & $\begin{array}{l}\text { IS2 } \\
\text { IS5 }\end{array}$ & JS4 & JU1 & $\begin{array}{l}\text { MA1 } \\
\text { MA2 } \\
\text { MA3 } \\
\text { MA4 } \\
\text { MA12 }\end{array}$ & $\mathrm{Y}$ & $\mathrm{T} 12$ \\
\hline Rainfall-runoff generation & Ca1 & CL14 & CM23 & $\mathrm{N}$ & LM5 & IS4 & JS5 & JU1 & $\begin{array}{l}\text { MA1 } \\
\text { MA2 } \\
\text { MA3 } \\
\text { MA4 } \\
\text { MA12 }\end{array}$ & & $\begin{array}{l}\text { T2 } \\
\text { T10 T11 }\end{array}$ \\
\hline Deep soil layers (>4m) & $\mathrm{Ca} 5 \mathrm{Ca} 1$ & CL12 & $\begin{array}{l}\text { CM11 } \\
\text { CM2 } \\
\text { CM19 } \\
\text { CM15 }\end{array}$ & $\mathrm{N}$ & LM1, LM5 & $\begin{array}{l}\text { IS11 } \\
\text { IS } 14\end{array}$ & JS4 & JU2 & $\begin{array}{l}\text { MA1 } \\
\text { MA2 } \\
\text { MA3 } \\
\text { MA4 }\end{array}$ & $\mathrm{Y}$ & $\mathrm{N}$ \\
\hline Organic soils & $\mathrm{Y}$ & $\begin{array}{l}\text { CL8 } \\
\text { CL15 }\end{array}$ & CM10 & $\begin{array}{l}\mathrm{CO} 4 \\
\mathrm{CO} 6\end{array}$ & LM7 & IS11 & $\mathrm{N}$ & $\mathrm{N}$ & $\mathrm{N}$ & $\mathrm{Y}$ & $\mathrm{T} 2$ \\
\hline Ponding and/or other & $\mathrm{Y}$ & CL14 & CM20 CM8 & $\mathrm{CO} 7$ & LM1 LM5 & $\mathrm{N}$ & $\mathrm{N}$ & $\mathrm{N}$ & $\mathrm{N}$ & & $\mathrm{T} 13$ \\
\hline Lateral flow in-grid/ hillslopes & $\mathrm{N}$ & $\mathrm{N}$ & CM21 & $\mathrm{N}$ & LM1 LM7 & IS15 & $\mathrm{N}$ & $\mathrm{N}$ & $\mathrm{N}$ & & $\mathrm{N}$ \\
\hline Layered snow & $\mathrm{Ca} 5$ & $\mathrm{~N}$ & CM7 & $\begin{array}{l}\mathrm{CO} 1 \\
\mathrm{CO} 2\end{array}$ & LM5 & $\begin{array}{l}\text { IS3 } \\
\text { IS4 } \\
\text { IS11 }\end{array}$ & $\mathrm{N}$ & JU1 & $\begin{array}{l}\text { MA1 } \\
\text { MA2 } \\
\text { MA3 } \\
\text { MA4 } \\
\text { MA9 } \\
\text { MA12 }\end{array}$ & OR5 & $\mathrm{T} 1 \mathrm{~T} 7$ \\
\hline
\end{tabular}


Table 4 Water bodies and hydrology

\begin{tabular}{|c|c|c|c|c|c|c|c|c|c|c|c|}
\hline & CABLE & CLASSIC & CLM & CoLM & $\mathrm{G} / \mathrm{LM}$ & ISBA & JSBACH & JULES & Matsiro & Orchidee & TESSEL \\
\hline River routing & $\mathrm{N}$ & CL3 & CM13 & $\mathrm{CO} 3$ & LM5 & $\begin{array}{l}\text { IS6 } \\
\text { IS14 } \\
\text { IS15 }\end{array}$ & JS6 & JU9 & $\begin{array}{l}\text { MA1 } \\
\text { MA2 } \\
\text { MA3 } \\
\text { MA4 MA10 } \\
\text { MA11 }\end{array}$ & $\mathrm{Y}$ & $\mathrm{Y}$ \\
\hline Wetlands and inundation & $\mathrm{N}$ & CL4 & $\begin{array}{l}\text { CM20 } \\
\text { CM16 } \\
\text { CM17 }\end{array}$ & $\mathrm{CO} 3$ & LM7 & $\begin{array}{l}\text { IS6 } \\
\text { IS14 }\end{array}$ & $\mathrm{N}$ & JU3 & $\begin{array}{l}\text { MA1 } \\
\text { MA2 } \\
\text { MA8 } \\
\text { MA10 }\end{array}$ & $\mathrm{N}$ & $\mathrm{Y}$ \\
\hline Irrigation & $\mathrm{Ca} 2$ & $\mathrm{~N}$ & CM12 CM22 & $\mathrm{N}$ & & & $\mathrm{N}$ & $\mathrm{Y}$ & $\begin{array}{l}\text { MA3 } \\
\text { MA4 } \\
\text { MA6 }\end{array}$ & $\mathrm{Y}$ & $\mathrm{Y}$ \\
\hline Groundwater & $\mathrm{Ca} 1$ & $\mathrm{~N}$ & CM14 CM19 & $\mathrm{CO} 3$ & LM5 & $\begin{array}{l}\text { IS10 } \\
\text { IS14 }\end{array}$ & $\mathrm{N}$ & $\mathrm{N}$ & $\begin{array}{l}\text { MA3 } \\
\text { MA4 } \\
\text { MA5 } \\
\text { MA7 }\end{array}$ & $\mathrm{N}$ & $\mathrm{Y}$ \\
\hline
\end{tabular}

Table 5 Soil biogeochemistry and plant physiology

\begin{tabular}{|c|c|c|c|c|c|c|c|c|c|c|c|}
\hline & CABLE & CLASSIC & CLM & CoLM & $\mathrm{G} / \mathrm{LM}$ & ISBA & JSBACH & JULES & Matsiro & Orchidee & TESSEL \\
\hline Photosynthesis responds to environment & $\mathrm{Y}$ & CL5 & $\mathrm{Y}$ & $\mathrm{Y}$ & $\mathrm{Y}$ & $\begin{array}{l}\text { IS1 } \\
\text { IS16 }\end{array}$ & $\mathrm{Y}$ & JU3 & $\begin{array}{l}\text { MA3 } \\
\text { MA4 }\end{array}$ & Y & $\mathrm{Y}$ \\
\hline $\begin{array}{l}\text { Allocation of carbon to roots, stems and } \\
\text { leaves. }\end{array}$ & $\mathrm{Y}$ & CL6 & $\mathrm{Y}$ & $\mathrm{Y}$ & $\mathrm{Y}$ & $\begin{array}{l}\text { IS17 } \\
\text { IS16 }\end{array}$ & JS7 & JU3 & MA3 & $\mathrm{Y}$ & $\mathrm{N}$ \\
\hline $\begin{array}{l}\text { Plants acclimatise to temperature and soil } \\
\text { moisture }\end{array}$ & $\mathrm{Y}$ & $\mathrm{N}$ & CM24 & $\mathrm{Y}$ & $\mathrm{N}$ & $\mathrm{N}$ & $\mathrm{N}$ & JU12 & $\mathrm{N}$ & $\mathrm{N}$ & $\mathrm{N}$ \\
\hline Soil carbon model & $\mathrm{Ca} 7$ & CL5 & CM9 & $\mathrm{N}$ & LM8 & $\begin{array}{l}\text { IS17 } \\
\text { IS16 }\end{array}$ & $\begin{array}{l}\text { JS1 } \\
\text { JS7 }\end{array}$ & JU3 & MA3 & $\mathrm{Y}$ & $\mathrm{N}$ \\
\hline Nitrogen cycle linked to carbon cycle & $\mathrm{Ca} 7$ & CL7 & CM5 & $\mathrm{N}$ & $\begin{array}{l}\text { LM2, } \\
\text { LM3, } \\
\text { LM8 }\end{array}$ & $\mathrm{N}$ & JS7 & JU15 & MA3 & OR4 & $\mathrm{N}$ \\
\hline
\end{tabular}

Table 6 Vegetation dynamics, land and water use

\begin{tabular}{|c|c|c|c|c|c|c|c|c|c|c|c|}
\hline & CABLE & CLASSIC & CLM & CoLM & G/LM & ISBA & JSBACH & JULES & Matsiro & Orchidee & TESSEL \\
\hline Different crop types & $\mathrm{N}$ & $\mathrm{N}$ & $\begin{array}{l}\text { CM4 } \\
\text { CM3 } \\
\text { CM25 }\end{array}$ & $\mathrm{N}$ & $\mathrm{N}$ & $\begin{array}{l}\text { IS9 } \\
\text { IS16 }\end{array}$ & $\mathrm{N}$ & $\begin{array}{l}\text { JU10 } \\
\text { JU11 }\end{array}$ & $\begin{array}{l}\text { MA3 } \\
\text { MA4 }\end{array}$ & $\mathrm{Y}$ & $\mathrm{T} 5$ \\
\hline Land use and land cover change & $\mathrm{Ca} 4$ & CL1 & $\mathrm{CM} 26$ & $\mathrm{~N}$ & $\mathrm{Y}$ & IS16 & JS2 & JU7 & MA4 & OR2 & $\mathrm{N}$ \\
\hline Competition between PFTs & $\mathrm{Y}$ & CL10 & $\mathrm{Y}$ & $\mathrm{Y}$ & Y & $\mathrm{N}$ & JS2 & $\begin{array}{l}\text { JU8 } \\
\text { JU14 }\end{array}$ & $\mathrm{N}$ & $\mathrm{Y}$ & $\mathrm{N}$ \\
\hline $\begin{array}{l}\text { Water use and transfers of water between } \\
\text { grid } \\
\text { cells }\end{array}$ & $\mathrm{N}$ & $\mathrm{N}$ & $\mathrm{N}$ & $\mathrm{N}$ & $\mathrm{N}$ & $\mathrm{N}$ & $\mathrm{N}$ & $\mathrm{N}$ & MA3 & $\mathrm{N}$ & $\mathrm{N}$ \\
\hline
\end{tabular}




\section{References (listed by model)}

\section{CABLE}

Ca1. Decker, M. (2015). Development and evaluation of a new soil moisture and runoff parameterization for the CABLE LSM including subgrid-scale processes. Journal of Advances in Modeling Earth Systems, 7(4), 1788-1809. 10.1002/ 2015MS000507

Ca2. Decker, M., Ma, S., \& Pitman, A. (2017). Local landatmosphere feedbacks limit irrigation demand. Environmental Research Letters, 12(5). 10.1088/1748-9326/aa65a6

Ca3. Haverd, V., Smith, B., Cook, G. D., Briggs, P. R., Nieradzik, L., Roxburgh, S. H., Liedloff, A., Meyer, C. P., \& Canadell, J. G. (2013). A stand-alone tree demography and landscape structure module for Earth system models. Geophysical Research Letters, 40(19), 5234-5239. 10.1002/ grl.50972

Ca4. Haverd, V., Smith, B., Nieradzik, L., Briggs, P. R., Woodgate, W., Trudinger, C. M., Canadell, J. G., \& Cuntz, M. (2018). A new version of the CABLE land surface model (Subversion revision r4601) incorporating land use and land cover change, woody vegetation demography, and a novel optimisation-based approach to plant coordination of photosynthesis. Geoscientific Model Development, 11(7), 29953026. 10.5194/gmd-11-2995-2018

Ca5. Kowalczyk, E. A., Wang, Y. P., Law, R. M., Davies, H. L., McGregor, J. L., \& Abramowitz, G. S. (2006). The CSIRO Atmosphere Biosphere Land Exchange (CABLE) model for use in climate models and as an offline model (No. 013; CSIRO Marine and Atmospheric Research Paper, p. 43). CSIRO Marine and Atmospheric Research. 10.4225/ 08/58615c6a9a51d

Ca6. Raupach, M. R. (1994). Simplified expressions for vegetation roughness length and zero-plane displacement as functions of canopy height and area index. Boundary-Layer Meteorology, 71(1-2), 211-216. 10.1007/BF00709229

Ca7. Wang, Y. P., Kowalczyk, E., Leuning, R., Abramowitz, G., Raupach, M. R., Pak, B., van Gorsel, E., \& Luhar, A. (2011). Diagnosing errors in a land surface model (CABLE) in the time and frequency domains. Journal of Geophysical Research: Biogeosciences, 116. 10.1029/ 2010JG00138

Ca8. Wang, Y.P. \& Leuning, R. (1998). A two-leaf model for canopy conductance, photosynthesis and partitioning of available energy I: Model description and comparison with a multi-layered model. Agricultural and Forest Meteorology, 91(1-2), 89-111. 10.1016/S0168-1923(98)00061-6

Ca9. Wang, Y. P., Law, R. M., \& Pak, B. (2010). A global model of carbon, nitrogen and phosphorus cycles for the terrestrial biosphere. Biogeosciences, 7(7), 2261-2282. 10.5194/ bg-7-2261-2010

CLASSIC
CL1. Arora, V. K., \& Boer, G. J. (2010). Uncertainties in the 20th century carbon budget associated with land use change. Global Change Biology, 16(12), 3327-3348. 10.1111/j.1365-2486.2010.02202.x

CL2. Arora, V. K., \& Boer, G. J. (2005). Fire as an interactive component of dynamic vegetation models. Journal of Geophysical Research: Biogeosciences, 110(G2). 10.1029/ 2005JG000042

CL3. Arora, V., \& Boer, G. (1999). A variable velocity flow routing algorithm for GCMs. Journal of Geophysical Research: Atmospheres, 104(D24), 30965-30979. 10.1029/ 1999JD900905

CL4. Arora, V. K., Melton, J. R., \& Plummer, D. (2018). An assessment of natural methane fluxes simulated by the CLASS-CTEM model. Biogeosciences, 15(15), 4683-4709. 10.5194/bg-15-4683-2018

CL5. Arora, Vivek K. (2003). Simulating energy and carbon fluxes over winter wheat using coupled land surface and terrestrial ecosystem models. Agricultural and Forest Meteorology, 118(1), 21-47. 10.1016/S01681923(03)00073-X

CL6. Arora, Vivek K., \& Boer, G. J. (2005a). A parameterization of leaf phenology for the terrestrial ecosystem component of climate models. Global Change Biology, 11(1), 3959. 10.1111/j.1365-2486.2004.00890.x

CL7. Asaadi, A., \& Arora, V. K. (2020). Implementation of nitrogen cycle in the CLASSIC land model. Biogeosciences Discussions, 1-87. 10.5194/bg-2020-147

CL8. Letts, M., Roulet, N., Comer, N., Skarupa, M., \& Verseghy, D. (2000). Parametrization of peatland hydraulic properties for the Canadian Land Surface Scheme. Atmosphere-Ocean, 38(1), 141-160.10.1080/ 07055900.2000.9649643

CL9: Melton, J. R., \& Arora, V. K. (2014). Sub-grid scale representation of vegetation in global land surface schemes: Implications for estimation of the terrestrial carbon sink. Biogeosciences, 11(4), 1021-1036. 10.5194/bg-11-10212014

CL10: Melton, J. R., \& Arora, V. K. (2016). Competition between plant functional types in the Canadian Terrestrial Ecosystem Model (CTEM) v.2.0. Geoscientific Model Development, 9(1), 323-361. 10.5194/gmd-9-323-2016

CL11: Melton, J. R., Sospedra-Alfonso, R., \& McCusker, K. E. (2017). Tiling soil textures for terrestrial ecosystem modelling via clustering analysis: A case study with CLASS-CTEM (version 2.1). Geoscientific Model Development, 10(7), 2761-2783. 10.5194/gmd-10-27612017

CL12: Melton, J.R., Verseghy, D. L., Sospedra-Alfonso, R., \& Gruber, S. (2019). Improving permafrost physics in the coupled Canadian Land Surface Scheme (v.3.6.2) and Canadian Terrestrial Ecosystem Model (v.2.1) (CLASS- 
CTEM). Geoscientific Model Development, 12(10), 44434467. 10.5194/gmd-12-4443-2019

CL13: Verseghy, D., McFarlane, N., \& Lazare, M. (1993). CLASS - A Canadian land surface scheme for GCMS .2. Vegetation model and coupled runs. International Journal of Climatology, 13(4), 347-370. 10.1002/joc.3370130402

CL14: Verseghy, D. (1991). CLASS - A Canadian land surface scheme for GCMS .1. Soil model. International Journal of Climatology, 11(2), 111-133. 10.1002

CL15: Wu, Y., Verseghy, D. L., \& Melton, J. R. (2016). Integrating peatlands into the coupled Canadian Land Surface Scheme (CLASS) v3.6 and the Canadian Terrestrial Ecosystem Model (CTEM) v2.0. Geoscientific Model Development, 9(8), 2639-2663. 10.5194/gmd-9-2639-2016

CLM:

CM1. Bonan, G. B., Patton, E. G., Harman, I. N., Oleson, K. W., Finnigan, J. J., Lu, Y., \& Burakowski, E. A. (2018). Modeling canopy-induced turbulence in the Earth system: A unified parameterization of turbulent exchange within plant canopies and the roughness sublayer (CLM-ml v0). Geoscientific Model Development, 11(4), 1467-1496. 10.5194/gmd-11-1467-2018

CM2. Brunke, M. A., Broxton, P., Pelletier, J., Gochis, D., Hazenberg, P., Lawrence, D. M., Leung, L. R., Niu, G.-Y., Troch, P. A., \& Zeng, X. (2016). Implementing and Evaluating Variable Soil Thickness in the Community Land Model, Version 4.5 (CLM4.5). Journal of Climate, 29(9), 3441-3461. 10.1175/JCLI-D-15-0307.1

CM3. Cheng, Y., Huang, M., Chen, M., Guan, K., Bernacchi, C., Peng, B., \& Tan, Z. (2020). Parameterizing Perennial Bioenergy Crops in Version 5 of the Community Land Model Based on Site-Level Observations in the Central Midwestern United States. Journal of Advances in Modeling Earth Systems, 12(1). 10.1029/2019MS001719

CM4. Drewniak, B., Song, J., Prell, J., Kotamarthi, V. R., \& Jacob, R. (2013). Modeling agriculture in the Community Land Model. Geoscientific Model Development, 6(2), 495515. 10.5194/gmd-6-495-2013

CM5. Fisher, R. A., Wieder, W. R., Sanderson, B. M., Koven, C. D., Oleson, K. W., Xu, C., Fisher, J. B., Shi, M., Walker, A. P., \& Lawrence, D. M. (2019). Parametric Controls on Vegetation Responses to Biogeochemical Forcing in the CLM5. Journal of Advances in Modeling Earth Systems, 11(9), 2879-2895. 10.1029/2019MS001609

CM6. Fox, A. M., Hoar, T. J., Anderson, J. L., Arellano, A. F., Smith, W. K., Litvak, M. E., MacBean, N., Schimel, D. S., \& Moore, D. J. P. (2018). Evaluation of a Data Assimilation System for Land Surface Models Using CLM4.5. Journal of Advances in Modeling Earth Systems, 10(10), 2471-2494. 10.1029/2018MS001362

CM7. van Kampenhout, L., Lenaerts, J. T. M., Lipscomb, W. H., Sacks, W. J., Lawrence, D. M., Slater, A. G., \& van den Broeke, M. R. (2017). Improving the Representation of
Polar Snow and Firn in the Community Earth System Model. Journal of Advances in Modeling Earth Systems, 9(7), 25832600. 10.1002/2017MS000988

CM8. Kennedy, D., Swenson, S., Oleson, K. W., Lawrence, D. M., Fisher, R., Lola da Costa, A. C., \& Gentine, P. (2019). Implementing Plant Hydraulics in the Community Land Model, Version 5. Journal of Advances in Modeling Earth Systems, 11(2), 485-513. 10.1029/ 2018MS001500

CM9. Koven, C. D., Riley, W. J., Subin, Z. M., Tang, J. Y., Torn, M. S., Collins, W. D., Bonan, G. B., Lawrence, D. M., $\&$ Swenson, S. C. (2013). The effect of vertically resolved soil biogeochemistry and alternate soil $\mathrm{C}$ and $\mathrm{N}$ models on $\mathrm{C}$ dynamics of CLM4. Biogeosciences, 10(11), 7109-7131. 10.5194/bg-10-7109-2013

CM10. Lawrence, D. M., \& Slater, A. G. (2008). Incorporating organic soil into a global climate model. Climate Dynamics, 30(2-3), 145-160. 10.1007/s00382-0070278-1

CM11. —, - Romanovsky, V. E., \& Nicolsky, D. J. (2008). Sensitivity of a model projection of nearsurface permafrost degradation to soil column depth and representation of soil organic matter. Journal of Geophysical Research: Earth Surface, 113(F2). 10.1029/2007JF000883

CM12. — and Coauthors (2019). The Community Land Model Version 5: Description of New Features, Benchmarking, and Impact of Forcing Uncertainty. Journal of Advances in Modeling Earth Systems, 11(12), 42454287. 10.1029/2018MS001583

CM13. Li, H.-Y., Leung, L. R., Getirana, A., Huang, M., Wu, H., Xu, Y., Guo, J., \& Voisin, N. (2015). Evaluating Global Streamflow Simulations by a Physically Based Routing Model Coupled with the Community Land Model. Journal of Hydrometeorology, 16(2), 948-971. 10.1175/ JHM-D-14-0079.1

CM14. Niu, G.-Y., Yang, Z.-L., Dickinson, R. E., Gulden, L. E., \& Su, H. (2007). Development of a simple groundwater model for use in climate models and evaluation with Gravity Recovery and Climate Experiment data. Journal of Geophysical Research: Atmospheres, 112(D7). 10.1029/ 2006JD007522

CM15. Pelletier, J. D., Broxton, P. D., Hazenberg, P., Zeng, X., Troch, P. A., Niu, G.-Y., Williams, Z., Brunke, M. A., \& Gochis, D. (2016). A gridded global data set of soil, intact regolith, and sedimentary deposit thicknesses for regional and global land surface modeling. Journal of Advances in Modeling Earth Systems, 8(1), 41-65. 10.1002/ 2015MS000526

CM16. Riley, W. J., Subin, Z. M., Lawrence, D. M., Swenson, S. C., Torn, M. S., Meng, L., Mahowald, N. M., \& Hess, P. (2011). Barriers to predicting changes in global terrestrial methane fluxes: Analyses using CLM4Me, a 
methane biogeochemistry model integrated in CESM. Biogeosciences, 8(7), 1925-1953. 10.5194/bg-8-1925-2011

CM17. Subin, Z. M., Riley, W. J., \& Mironov, D. (2012). An improved lake model for climate simulations: Model structure, evaluation, and sensitivity analyses in CESM1. Journal of Advances in Modeling Earth Systems, 4. 10.1029/ 2011MS000072

CM18. Swenson, S. C., \& Lawrence, D. M. (2012). A new fractional snow-covered area parameterization for the Community Land Model and its effect on the surface energy balance. Journal of Geophysical Research: Atmospheres, 117. 10.1029/2012JD018178

CM19. Swenson, S. C., \& Lawrence, D. M. (2015). A GRACE-based assessment of interannual groundwater dynamics in the Community Land Model. Water Resources Research, 51(11), 8817-8833. 10.1002/2015WR017582

CM20. — , - a and H. Lee, (2012). Improved simulation of the terrestrial hydrological cycle in permafrost regions by the Community Land Model. Journal of Advances in Modeling Earth Systems, 4. 10.1029/2012MS00016

CM21. Swenson, Sean C., Clark, M., Fan, Y., Lawrence, D. M., \& Perket, J. (2019). Representing Intrahillslope Lateral Subsurface Flow in the Community Land Model. Journal of Advances in Modeling Earth Systems, 11(12), 4044-4065. 10.1029/2019MS001833

CM22. Thiery, W., Davin, E. L., Lawrence, D. M., Hirsch, A. L., Hauser, M., \& Seneviratne, S. I. (2017). Present-day irrigation mitigates heat extremes. Journal of Geophysical Research: Atmospheres, 122(3), 1403-1422. 10.1002/ 2016JD025740

CM23. Niu, G.-Y., Yang, Z.-L., Dickinson, R. E., \& Gulden, L. E. (2005). A simple TOPMODEL-based runoff parameterization (SIMTOP) for use in global climate models. Journal of Geophysical Research: Atmospheres, 110(D21). 10.1029/2005JD006111

CM24. Lombardozzi, D. L., Bonan, G. B., Smith, N. G., Dukes, J. S., \& Fisher, R. A. (2015). Temperature acclimation of photosynthesis and respiration: A key uncertainty in the carbon cycle-climate feedback. In Geophysical Research Letters (Vol. 42, Issue 20, pp. 8624-8631). 10.1002/ 2015GL065934

CM25. Lombardozzi, D. L., Lu, Y., Lawrence, P. J., Lawrence, D. M., Swenson, S., Oleson, K. W., Wieder, W. R., \& Ainsworth, E. A. (2020). Simulating Agriculture in the Community Land Model Version 5. Journal of Geophysical Research: Biogeosciences, 125(8), e2019JG005529. 10.1029/ 2019JG005529

CM26. Lawrence, P. J., Lawrence, D. M., \& Hurtt, G. C. (2018). Attributing the Carbon Cycle Impacts of CMIP5 Historical and Future Land Use and Land Cover Change in the Community Earth System Model (CESM1). Journal of Geophysical Research: Biogeosciences, 123(5), 1732-1755. 10.1029/2017JG004348

\section{CoLM}

CO1. Dai, Yongjiu, \& Zeng, Q. (1997). A land surface model (IAP94) for climate studies part I: Formulation and validation in off-line experiments. Advances in Atmospheric Sciences, 14(4), 433-460. 10.1007/s00376-997-0063-4

CO2. Dai, YJ, Zeng, X., Dickinson, R., Baker, I., Bonan, G., Bosilovich, M., Denning, A., Dirmeyer, P., Houser, P., Niu, G., Oleson, K., Schlosser, C., \& Yang, Z. (2003). The Common Land Model. Bulletin of the American Meteorological Society, 84(8), 1013-1023. 10.1175/BAMS84-8-1013

CO3. Dai, Y, Yuan, H., \& Zhang, S. (2014). The common land model (CoLM) version 2014. Beijing Normal University. http://globalchange.bnu.edu.cn/research/models

CO4. Dai, Yongjiu, Xin, Q., Wei, N., Zhang, Y., Shangguan, W., Yuan, H., Zhang, S., Liu, S., \& Lu, X. (2019). A Global High-Resolution Data Set of Soil Hydraulic and Thermal Properties for Land Surface Modeling. Journal of Advances in Modeling Earth Systems, 11(9), 2996-3023. 10.1029/2019MS001784

CO5. Dai, Yongjiu, Yuan, H., Xin, Q., Wang, D., Shangguan, W., Zhang, S., Liu, S., \& Wei, N. (2019). Different representations of canopy structure-A large source of uncertainty in global land surface modeling. Agricultural and Forest Meteorology, 269, 119-135. 10.1016/ j.agrformet.2019.02.006

CO6. Dai, Yongjiu, Wei, N., Yuan, H., Zhang, S., Shangguan, W., Liu, S., Lu, X., \& Xin, Y. (2019). Evaluation of Soil Thermal Conductivity Schemes for Use in Land Surface Modeling. Journal of Advances in Modeling Earth Systems, 11(11), 3454-3473. 10.1029/ 2019MS001723

CO7. Dai, Yongjiu, Zhang, S., Yuan, H., \& Wei, N. (2019). Modeling Variably Saturated Flow in Stratified Soils With Explicit Tracking of Wetting Front and Water Table Locations. Water Resources Research, 55(10), 7939 7963. 10.1029/2019WR025368

CO8. Shangguan, W., Dai, Y., Duan, Q., Liu, B., \& Yuan, H. (2014). A global soil data set for earth system modeling. Journal of Advances in Modeling Earth Systems, 6(1), 249263. 10.1002/2013MS000293

CO9. Shangguan, W., Hengl, T., de Jesus, J. M., Yuan, H., \& Dai, Y. (2017). Mapping the global depth to bedrock for land surface modeling. Journal of Advances in Modeling Earth Systems, 9(1), 65-88. 10.1002/2016MS000686

CO10. Yuan, H., Dickinson, R. E., Dai, Y., Shaikh, M. J., Zhou, L., Shangguan, W., \& Ji, D. (2014). A 3D Canopy Radiative Transfer Model for Global Climate Modeling: Description, Validation, and Application. Journal of Climate, 27(3), 1168-1192. 10.1175/JCLI-D-13-00155.1

\section{GFDL/LM}

LM1. Chaney, N. W., Van Huijgevoort, M. H. J., Shevliakova, E., Malyshev, S., Milly, P. C. D., Gauthier, P. 
P. G., \& Sulman, B. N. (2018). Harnessing big data to rethink land heterogeneity in Earth system models. Hydrology and Earth System Sciences, 22(6), 3311-3330. 10.5194/hess-223311-2018

LM2. Gerber, S., Hedin, L. O., Oppenheimer, M., Pacala, S. W., \& Shevliakova, E. (2010). Nitrogen cycling and feedbacks in a global dynamic land model. Global Biogeochemical Cycles, 24. 10.1029/2008GB00333

LM3. Lee, M., Malyshev, S., Shevliakova, E., Milly, P. C. D., \& Jaffe, P. R. (2014). Capturing interactions between nitrogen and hydrological cycles under historical climate and land use: Susquehanna watershed analysis with the GFDL land model LM3-TAN. Biogeosciences, 11(20), 5809-5826. 10.5194/bg-11-5809-2014

LM4. Li, D., Malyshev, S., \& Shevliakova, E. (2016). Exploring historical and future urban climate in the Earth System Modeling framework: 1. Model development and evaluation. Journal of Advances in Modeling Earth Systems, 8(2), 917-935. 10.1002/2015MS000578

LM5. Milly, P. C. D., Malyshev, S. L., Shevliakova, E., Dunne, K. A., Findell, K. L., Gleeson, T., Liang, Z., Phillipps, P., Stouffer, R. J., \& Swenson, S. (2014). An Enhanced Model of Land Water and Energy for Global Hydrologic and EarthSystem Studies. Journal of Hydrometeorology, 15(5), 1739 1761. 10.1175/JHM-D-13-0162.1

LM6. Rabin, S. S., Ward, D. S., Malyshev, S. L., Magi, B. I., Shevliakova, E., \& Pacala, S. W. (2018). A fire model with distinct crop, pasture, and non-agricultural burning: Use of new data and a model-fitting algorithm for FINAL.1. Geoscientific Model Development, 11(2), 815-842. 10.5194/ gmd-11-815-2018

LM7. Subin, Z. M., Milly, P. C. D., Sulman, B. N., Malyshev, S., \& Shevliakova, E. (2014). Resolving terrestrial ecosystem processes along a subgrid topographic gradient for an earth-system model. Hydrology and Earth System Sciences, 11, 8443-8492. USGS Publications Warehouse. 10.5194/hessd-11-8443-2014

LM8. Sulman, B. N., Shevliakova, E., Brzostek, E. R., Kivlin, S. N., Malyshev, S., Menge, D. N. L., \& Zhang, X. (2019). Diverse Mycorrhizal Associations Enhance Terrestrial C Storage in a Global Model. Global Biogeochemical Cycles, 33(4), 501-523. 10.1029/2018GB005973

LM9. Shevliakova, E., Pacala, S. W., Malyshev, S., Hurtt, G. C., Milly, P. C. D., Caspersen, J. P., Sentman, L. T., Fisk, J. P., Wirth, C., \& Crevoisier, C. (2009). Carbon cycling under 300 years of land use change: Importance of the secondary vegetation sink. Global Biogeochemical Cycles, 23. 10.1029/ 2007GB003176

LM10. Ward, D. S., Shevliakova, E., Malyshev, S., \& Rabin, S. (2018). Trends and Variability of Global Fire Emissions Due To Historical Anthropogenic Activities. Global Biogeochemical Cycles, 32(1), 122-142. 10.1002/ 2017GB005787
ISBA

IS 1: Calvet, J.-C., Noilhan, J., Roujean, J.-L., Bessemoulin, P., Cabelguenne, M., Olioso, A., \& Wigneron, J.-P. (1998). An interactive vegetation SVAT model tested against data from six contrasting sites. Agricultural and Forest Meteorology, 92(2), 73-95. 10.1016/S01681923(98)00091-4

IS2. Boone, A., Masson, V., Meyers, T., \& Noilhan, J. (2000). The Influence of the Inclusion of Soil Freezing on Simulations by a Soil-Vegetation-Atmosphere Transfer Scheme. Journal of Applied Meteorology and Climatology, 39 (9) , $1544-1569$. $10.1175 / 1520$ 0450(2000)039<1544:TIOTIO >2.0.CO;2

IS3: Boone, A, \& Etchevers, P. (2001). An Intercomparison of Three Snow Schemes of Varying Complexity Coupled to the Same Land Surface Model: Local-Scale Evaluation at an Alpine Site. Journal of Hydrometeorology, 2(4), 374-394. 10.1175/15257541(2001)002<0374:AIOTSS>2.0.CO;2

IS4: Decharme, B., \& Douville, H. (2006). Introduction of a sub-grid hydrology in the ISBA land surface model. Climate Dynamics, 26(1), 65-78. 10.1007/s00382-005-0059-7

IS5: Decharme, B., Boone, A., Delire, C., \& Noilhan, J. (2011). Local evaluation of the Interaction between Soil Biosphere Atmosphere soil multilayer diffusion scheme using four pedotransfer functions. Journal of Geophysical Research: Atmospheres, 116(D20). 10.1029/2011JD016002

IS6: Decharme, B., Alkama, R., Papa, F., Faroux, S., Douville, H., \& Prigent, C. (2012). Global off-line evaluation of the ISBA-TRIP flood model. Climate Dynamics, 38(7), 1389-1412. 10.1007/s00382-011-1054-9

IS7: Vionnet, V., Brun, E., Morin, S., Boone, A., Faroux, S., Le Moigne, P., Martin, E., \& Willemet, J.-M. (2012). The detailed snowpack scheme Crocus and its implementation in SURFEX v7.2. Geoscientific Model Development, 5(3), 773 791. 10.5194/gmd-5-773-2012

IS8: Carrer, D., Roujean, J.-L., Lafont, S., Calvet, J.-C., Boone, A., Decharme, B., Delire, C., \& Gastellu-Etchegorry, J.-P. (2013). A canopy radiative transfer scheme with explicit FAPAR for the interactive vegetation model ISBA-A-gs: Impact on carbon fluxes. Journal of Geophysical Research: Biogeosciences, 118(2), 888-903. 10.1002/jgrg.20070

IS9: Masson, V., Le Moigne, P., Martin, E., Faroux, S., Alias, A., Alkama, R., Belamari, S., Barbu, A., Boone, A., Bouyssel, F., Brousseau, P., Brun, E., Calvet, J.-C., Carrer, D., Decharme, B., Delire, C., Donier, S., Essaouini, K., Gibelin, A.-L., ... Voldoire, A. (2013). The SURFEXv7.2 land and ocean surface platform for coupled or offline simulation of earth surface variables and fluxes. Geoscientific Model Development, 6(4), 929-960. 10.5194/gmd-6-9292013

IS10: Vergnes, J.-P., Decharme, B., \& Habets, F. (2014). Introduction of groundwater capillary rises using subgrid 
spatial variability of topography into the ISBA land surface model. Journal of Geophysical Research: Atmospheres, 119(19), 11,065-11,086. 10.1002/2014JD021573

IS11: Decharme, B., Brun, E., Boone, A., Delire, C., Le Moigne, P., \& Morin, S. (2016). Impacts of snow and organic soils parameterization on northern Eurasian soil temperature profiles simulated by the ISBA land surface model. The Cryosphere, 10(2), 853-877. 10.5194/tc-10-853-2016

IS12: Boone, A, Samuelsson, P., Gollvik, S., Napoly, A., Jarlan, L., Brun, E., \& Decharme, B. (2017). The interactions between soil-biosphere-atmosphere land surface model with a multi-energy balance (ISBA-MEB) option in SURFEXv8 Part 1: Model description. Geoscientific Model Development, 10(2), 843-872. 10.5194/gmd-10-843-2017

IS13: Napoly, A., Boone, A., Samuelsson, P., Gollvik, S., Martin, E., Seferian, R., Carrer, D., Decharme, B., \& Jarlan, L. (2017). The interactions between soil-biosphere-atmosphere (ISBA) land surface model multi-energy balance (MEB) option in SURFEXv8 - Part 2: Introduction of a litter formulation and model evaluation for local-scale forest sites. Geoscientific Model Development, 10(4), 1621-1644. 10.5194/gmd-10-1621-2017

IS14: Decharme, B., Delire, C., Minvielle, M., Colin, J., Vergnes, J.-P., Alias, A., Saint-Martin, D., Séférian, R., Sénési, S., \& Voldoire, A. (2019). Recent Changes in the ISBA-CTRIP Land Surface System for Use in the CNRMCM6 Climate Model and in Global Off-Line Hydrological Applications. Journal of Advances in Modeling Earth Systems, 11(5), 1207-1252. 10.1029/2018MS001545

IS15: Le Moigne, P., Besson, F., Martin, E., Boé, J., Boone, A., Decharme, B., Etchevers, P., Faroux, S., Habets, F., Lafaysse, M., Leroux, D., \& Rousset-Regimbeau, F. (2020). The latest improvements with SURFEX v8.0 of the Safran-Isba-Modcou hydrometeorological model for France. Geoscientific Model Development, 13(9), 3925-3946. 10.5194/gmd-13-3925-2020

IS16: Delire, C., Séférian, R., Decharme, B., Alkama, R., Calvet, J.-C., Carrer, D., Gibelin, A.-L., Joetzjer, E., Morel, X., Rocher, M., \& Tzanos, D. (2020). The Global Land Carbon Cycle Simulated With ISBA-CTRIP: Improvements Over the Last Decade. Journal of Advances in Modeling Earth Systems, 12(9), e2019MS001886. 10.1029/2019MS001886

IS17: Gibelin, A.-L., Calvet, J.-C., \& Viovy, N. (2008). Modelling energy and $\mathrm{CO} 2$ fluxes with an interactive vegetation land surface model-Evaluation at high and middle latitudes. Agricultural and Forest Meteorology, 148(10), 16111628. 10.1016/j.agrformet.2008.05.013

\section{JULES}

JU1. Best, M. J., Pryor, M., Clark, D. B., Rooney, G. G., Essery, R. L. H., Menard, C. B., Edwards, J. M., Hendry, M. A., Porson, A., Gedney, N., Mercado, L. M., Sitch, S., Blyth, E., Boucher, O., Cox, P. M., Grimmond, C. S. B., \& Harding, R. J. (2011). The Joint UK Land Environment Simulator
(JULES), model description-Part 1: Energy and water fluxes. Geoscientific Model Development, 4(3), 677-699. 10.5194/gmd-4-677-2011

JU2. Burke, E. J., Chadburn, S. E., \& Ekici, A. (2017). A vertical representation of soil carbon in the JULES land surface scheme (vn4.3 permafrost) with a focus on permafrost regions. Geoscientific Model Development, 10(2), 959-975. 10.5194/gmd-10-959-2017

JU3. Clark, D. B., Mercado, L. M., Sitch, S., Jones, C. D., Gedney, N., Best, M. J., Pryor, M., Rooney, G. G., Essery, R. L. H., Blyth, E., Boucher, O., Harding, R. J., Huntingford, C., \& Cox, P. M. (2011). The Joint UK Land Environment Simulator (JULES), model description - Part 2: Carbon fluxes and vegetation dynamics. Geoscientific Model Development, 4(3), 701-722. 10.5194/gmd-4-701-2011

JU4. Dadson, S. J., Ashpole, I., Harris, P., Davies, H. N., Clark, D. B., Blyth, E., \& Taylor, C. M. (2010). Wetland inundation dynamics in a model of land surface climate: Evaluation in the Niger inland delta region. Journal of Geophysical Research: Atmospheres, 115. 10.1029/ 2010JD014474

JU5. Essery, R., Best, M., Betts, R., Cox, P., \& Taylor, C. (2003). Explicit representation of subgrid heterogeneity in a GCM land surface scheme. Journal of Hydrometeorology, 4(3), 530-543. 10.1175/15257541(2003)004<0530:EROSHI>2.0.CO;2

JU6. Mercado, L. M., Huntingford, C., Gash, J. H. C., Cox, P. M., \& Jogireddy, V. (2007). Improving the representation of radiation interception and photosynthesis for climate model applications. Tellus B, 59(3), 553-565. 10.1111/j.16000889.2007.00256.x

JU7. Burton, C., Betts, R., Cardoso, M., Feldpausch, T. R., Harper, A., Jones, C. D., Kelley, D. I., Robertson, E., \& Wiltshire, A. (2019). Representation of fire, land-use change and vegetation dynamics in the Joint UK Land Environment Simulator vn4.9 (JULES). Geoscientific Model Development, 12(1), 179-193. 10.5194/gmd-12-179-2019

JU8. Harper, A. B., Wiltshire, A. J., Cox, P. M., Friedlingstein, P., Jones, C. D., Mercado, L. M., Sitch, S., Williams, K., \& Duran-Rojas, C. (2018). Vegetation distribution and terrestrial carbon cycle in a carbon cycle configuration of JULES4.6 with new plant functional types. Geoscientific Model Development, 11(7), 2857-2873. 10.5194/gmd-11-2857-2018

JU9. Martínez-de la Torre, A., Blyth, E. M., \& Weedon, G. P. (2019). Using observed river flow data to improve the hydrological functioning of the JULES land surface model (vn4.3) used for regional coupled modelling in Great Britain (UKC2). Geoscientific Model Development, 12(2), 765-784. 10.5194/gmd-12-765-2019

JU10. Williams, K., Gornall, J., Harper, A., Wiltshire, A., Hemming, D., Quaife, T., Arkebauer, T., \& Scoby, D. (2017). Evaluation of JULES-crop performance against site 
observations of irrigated maize from Mead, Nebraska. Geoscientific Model Development, 10(3), 1291-1320. 10.5194/gmd-10-1291-2017

JU11. Osborne, T., Gornall, J., Hooker, J., Williams, K., Wiltshire, A., Betts, R., \& Wheeler, T. (2015). JULES-crop: A parametrisation of crops in the Joint UK Land Environment Simulator. Geoscientific Model Development, 8(4), 11391155. 10.5194/gmd-8-1139-2015

JU12. Williams, K. E., Harper, A. B., Huntingford, C., Mercado, L. M., Mathison, C. T., Falloon, P. D., Cox, P. M., \& Kim, J. (2019). How can the First ISLSCP Field Experiment contribute to present-day efforts to evaluate water stress in JULESv5.0? Geoscientific Model Development, 12(7), 3207-3240. 10.5194/gmd-12-3207-2019

JU13. Harper, A. B., Cox, P. M., Friedlingstein, P., Wiltshire, A. J., Jones, C. D., Sitch, S., Mercado, L. M., Groenendijk, M., Robertson, E., Kattge, J., Bönisch, G., Atkin, O. K., Bahn, M., Cornelissen, J., Niinemets, Ü., Onipchenko, V., Peñuelas, J., Poorter, L., Reich, P. B., ... Bodegom, P. van. (2016). Improved representation of plant functional types and physiology in the Joint UK Land Environment Simulator (JULES v4.2) using plant trait information. Geoscientific Model Development, 9(7), 2415-2440. 10.5194/gmd-9-2415-2016

JU14. Wiltshire, A. J., Duran Rojas, M. C., Edwards, J. M., Gedney, N., Harper, A. B., Hartley, A. J., Hendry, M. A., Robertson, E., \& Smout-Day, K. (2020). JULES-GL7: The Global Land configuration of the Joint UK Land Environment Simulator version 7.0 and 7.2. Geoscientific Model Development, 13(2), 483-505. 10.5194/gmd-13-483-2020

JU15. Wiltshire, A. J., Burke, E. J., Chadburn, S. E., Jones, C. D., Cox, P. M., Davies-Barnard, T., Friedlingstein, P., Harper, A. B., Liddicoat, S., Sitch, S. A., \& Zaehle, S. (2020). JULES-CN: a coupled terrestrial Carbon-Nitrogen Scheme (JULES vn5.1). Geoscientific Model Development Discussions, 2020, 1-40. 10.5194/gmd-2020-205

\section{JSBACH}

JS1. Mauritsen, T., Bader, J., Becker, T., Behrens, J., Bittner, M., Brokopf, R., Brovkin, V., Claussen, M., Crueger, T., Esch, M., Fast, I., Fiedler, S., Flaeschner, D., Gayler, V., Giorgetta, M., Goll, D. S., Haak, H., Hagemann, S., Hedemann, C., ... Roeckner, E. (2019). Developments in the MPI-M Earth System Model version 1.2 (MPI-ESM1.2) and Its Response to Increasing CO2. Journal of Advances in Modeling Earth Systems, 11(4), 998-1038. 10.1029/ 2018MS001400

JS2. Reick, C. H., Raddatz, T., Brovkin, V., \& Gayler, V. (2013). Representation of natural and anthropogenic land cover change in MPI-ESM. Journal of Advances in Modeling Earth Systems, 5(3), 459-482. 10.1002/jame.20022

JS3. Roeckner, E., Bäuml, G., Bonaventura, L., Brokopf, R., Esch, M., Giorgetta, M., Hagemann, S., Kirchner, I., Kornblueh, L., Manzini, E., Rhodin, A., Schlese, U.,
Schulzweida, U., \& Tompkins, A. (2003). The atmospheric general circulation model ECHAM 5. PART I: model description. Max Planck Institute for Meteorology Report, 349.

JS4. Hagemann, S., \& Stacke, T. (2015). Impact of the soil hydrology scheme on simulated soil moisture memory. Climate Dynamics, 44(7-8), 1731-1750. 10.1007/s00382014-2221-6

JS5. Dümenil, L., \& Todini, E. (1992). A rainfall-runoff scheme for use in the Hamburg climate model. In J. P. Kane (Ed.), Advances in Theoretical Hydrology: A tribute to James Dooge (pp. 129-157). Elsevier Science Publishers B.V.

JS6. Hagemann, S., \& Dümenil, L. (1997). A parametrization of the lateral waterflow for the global scale. Climate Dynamics, 14(1), 17-31. 10.1007/s003820050205

JS7. Goll, Daniel S., Winkler, A. J., Raddatz, T., Dong, N., Prentice, I. C., Ciais, P., \& Brovkin, V. (2017). Carbonnitrogen interactions in idealized simulations with JSBACH (version 3.10). Geoscientific Model Development, 10(5), 2009-2030. 10.5194/gmd-10-2009-2017

\section{MATSIRO}

The first 4 (MA1-4) are the latest 4 "flavors" of MATSIRO-based models. In these models, MATSIRO works as a typical land surface model, and some other models are coupled to represent different features. The latter (MA5-11) are the works in which individual processes were implemented / improved. The last one (MA12) is the original version.

MA1. (MIROC6) Tatebe, H., Ogura, T., Nitta, T., Komuro, Y., Ogochi, K., Takemura, T., Sudo, K., Sekiguchi, M., Abe, M., Saito, F., Chikira, M., Watanabe, S., Mori, M., Hirota, N., Kawatani, Y., Mochizuki, T., Yoshimura, K., Takata, K., O'ishi, R., ... Kimoto, M. (2019). Description and basic evaluation of simulated mean state, internal variability, and climate sensitivity in MIROC6. Geoscientific Model Development, 12(7), 2727-2765. 10.5194/gmd-12-27272019

MA2. Nitta, Tomoko, Arakawa, T., Hatono, M., Takeshima, A., \& Yoshimura, K. (2020). Development of Integrated Land Simulator. Progress in Earth and Planetary Science, 7(1), 68. 10.1186/s40645-020-00383-7

MA3. (MIROC-ESM) Hajima, T., Watanabe, M., Yamamoto, A., Tatebe, H., Noguchi, M. A., Abe, M., Ohgaito, R., Ito, A., Yamazaki, D., Okajima, H., Ito, A., Takata, K., Ogochi, K., Watanabe, S., \& Kawamiya, M. (2020). Development of the MIROC-ES2L Earth system model and the evaluation of biogeochemical processes and feedbacks. Geoscientific Model Development, 13(5), 2197 2244. 10.5194/gmd-13-2197-2020

MA4. (MIROC-INTEG) Yokohata, T., Kinoshita, T., Sakurai, G., Pokhrel, Y., Ito, A., Okada, M., Satoh, Y., Kato, E., Nitta, T., Fujimori, S., Felfelani, F., Masaki, Y., Iizumi, T., Nishimori, M., Hanasaki, N., Takahashi, K., Yamagata, Y., \& Emori, S. (2019). MIROC-INTEG1: A global bio-geochemical land surface model with human water 
management, crop growth, and land-use change. Geoscientific Model Development Discussions, 1-57. 10.5194/gmd-2019-184

MA5. (ground water table) Koirala, S., Yeh, P. J.-F., Hirabayashi, Y., Kanae, S., \& Oki, T. (2014). Global-scale land surface hydrologic modeling with the representation of water table dynamics. Journal of Geophysical Research: Atmospheres, 119(1), 75-89. 10.1002/2013JD020398

MA6. (irrigation) Pokhrel, Y., Hanasaki, N., Koirala, S., Cho, J., Yeh, P. J.-F., Kim, H., Kanae, S., \& Oki, T. (2012). Incorporating Anthropogenic Water Regulation Modules into a Land Surface Model. Journal of Hydrometeorology, 13(1), 255-269. 10.1175/JHM-D-11-013.1

MA7. (3D ground water) Miura, Y., \& Yoshimura, K. (2020). Development and Verification of a ThreeDimensional Variably Saturated Flow Model for Assessment of Future Global Water Resources. Journal of Advances in Modeling Earth Systems, 12(8), e2020MS002093. 10.1029/ 2020MS002093

MA8. (wetland) Nitta, Tomoko, Yoshimura, K., \& AbeOuchi, A. (2017). Impact of Arctic Wetlands on the Climate System: Model Sensitivity Simulations with the MIROC5 AGCM and a Snow-Fed Wetland Scheme. Journal of Hydrometeorology, 18(11), 2923-2936. 10.1175/JHM-D16-0105.1

MA9. (snow cover) Nitta, T., Yoshimura, K., Takata, K., O'ishi, R., Sueyoshi, T., Kanae, S., Oki, T., Abe-Ouchi, A., \& Liston, G. E. (2014). Representing Variability in Subgrid Snow Cover and Snow Depth in a Global Land Model: Offline Validation. Journal of Climate, 27(9), 3318-3330. 10.1175/JCLI-D-13-00310.1

MA10. (flood inundation) Yamazaki, D., Kanae, S., Kim, H., \& Oki, T. (2011). A physically based description of floodplain inundation dynamics in a global river routing model. Water Resources Research, 47(4). 10.1029/2010WR009726

MA11. (river flow) Yoshimura, K., Sakimura, T., Oki, T., Kanae, S., \& Seto, S. (2008). Toward flood risk prediction: A statistical approach using a 29-year river discharge simulation over Japan. Hydrological Research Letters, 2, 22-26. 10.3178/hrl.2.22

MA12. (original) Takata, K., Emori, S., \& Watanabe, T. (2003). Development of the minimal advanced treatments of surface interaction and runoff. Global and Planetary Change, 38(1), 209-222. 10.1016/S0921-8181(03)00030-4

Orchidee

OR1. https://ccdas.lsce.ipsl.fr/publications.php

OR2. Vuichard, N., Messina, P., Luyssaert, S., Guenet, B., Zaehle, S., Ghattas, J., Bastrikov, V., \& Peylin, P. (2019). Accounting for carbon and nitrogen interactions in the global terrestrial ecosystem model ORCHIDEE (trunk version, rev 4999): Multi-scale evaluation of gross primary production. Geoscientific Model Development, 12(11), 4751-4779. 10.5194/gmd-12-4751-2019
OR3. Ryder, J., Polcher, J., Peylin, P., Ottle, C., Chen, Y., van Gorsel, E., Haverd, V., McGrath, M. J., Naudts, K., Otto, J., Valade, A., \& Luyssaert, S. (2016). A multi-layer land surface energy budget model for implicit coupling with global atmospheric simulations. Geoscientific Model Development, 9(1), 223-245. 10.5194/gmd-9-223-2016

OR4. Vuichard, N., Messina, P., Luyssaert, S., Guenet, B., Zaehle, S., Ghattas, J., Bastrikov, V., \& Peylin, P. (2019). Accounting for carbon and nitrogen interactions in the global terrestrial ecosystem model ORCHIDEE (trunk version, rev 4999): Multi-scale evaluation of gross primary production. Geoscientific Model Development, 12(11), 4751-4779. 10.5194/gmd-12-4751-2019

OR5. Wang, T., Ottle, C., Boone, A., Ciais, P., Brun, E., Morin, S., Krinner, G., Piao, S., \& Peng, S. (2013). Evaluation of an improved intermediate complexity snow scheme in the ORCHIDEE land surface model. Journal of Geophysical Research: Atmospheres, 118(12), 6064-6079. 10.1002/ jgrd. 50395

TESSEL

T1. Arduini, G., Balsamo, G., Dutra, E., Day, J. J., Sandu, I., Boussetta, S., \& Haiden, T. (2019). Impact of a Multi-Layer Snow Scheme on Near-Surface Weather Forecasts. Journal of Advances in Modeling Earth Systems, 11(12), 4687-4710. 10.1029/2019MS001725

T2. Balsamo, G., Viterbo, P., Beljaars, A., van den Hurk, B., Hirschi, M., Betts, A. K., \& Scipal, K. (2009). A Revised Hydrology for the ECMWF Model: Verification from Field Site to Terrestrial Water Storage and Impact in the Integrated Forecast System. Journal of Hydrometeorology, 10(3), 623643. 10.1175/2008JHM1068.1

T3. Balsamo, G., Albergel, C., Beljaars, A., Boussetta, S., Brun, E., Cloke, H., Dee, D., Dutra, E., Munoz-Sabater, J., Pappenberger, F., de Rosnay, P., Stockdale, T., \& Vitart, F. (2015). ERA-Interim/Land: A global land surface reanalysis data set. Hydrology and Earth System Sciences, 19(1), 389407. 10.5194/hess-19-389-2015

T4. Balsamo, G., Agusti-Panareda, A., Albergel, C., Arduini, G., Beljaars, A., Bidlot, J., Blyth, E., Bousserez, N., Boussetta, S., Brown, A., Buizza, R., Buontempo, C., Chevallier, F., Choulga, M., Cloke, H., Cronin, M. F., Dahoui, M., De Rosnay, P., Dirmeyer, P. A., ... Zeng, X. (2019). Observations for Advancing Global Earth Surface Modelling: A Review (vol 10, 2038, 2018). Remote Sensing, 11(8). 10.3390/rs1 1080941

T5. Boussetta, S., Balsamo, G., Beljaars, A., Panareda, A.A., Calvet, J.-C., Jacobs, C., van den Hurk, B., Viterbo, P., Lafont, S., Dutra, E., Jarlan, L., Balzarolo, M., Papale, D., \& van der Werf, G. (2013). Natural land carbon dioxide exchanges in the ECMWF integrated forecasting system: Implementation and offline validation. Journal of Geophysical Research: Atmospheres, 118(12), 5923-5946. $10.1002 /$ jgrd. 50488 
T6. Patricia de Rosnay, L. Isaksen, Mohamed Dahoui (2015) Snow data assimilation at ECMWF, ECMWF Newsletter, issue 143, pp. 26-31. DOI: 10.21957/lkpxq6x5

T7. Dutra, E., Viterbo, P., Miranda, P. M. A., \& Balsamo, G. (2012). Complexity of Snow Schemes in a Climate Model and Its Impact on Surface Energy and Hydrology. Journal of Hydrometeorology, 13(2), 521-538. 10.1175/JHM-D-11-072.1

T8. Hogan, R. J. (2019). Flexible Treatment of Radiative Transfer in Complex Urban Canopies for Use in Weather and Climate Models. Boundary-Layer Meteorology, 173(1), 5378. 10.1007/s10546-019-00457-0

T9. Orth, R., Dutra, E., \& Pappenberger, F. (2016). Improving Weather Predictability by Including Land Surface Model Parameter Uncertainty. Monthly Weather Review, 144(4), 1551-1569. 10.1175/MWR-D-15-0283.1

T10. Orth, R., Dutra, E., Trigo, I. F., \& Balsamo, G. (2017). Advancing land surface model development with satellitebased Earth observations. Hydrology and Earth System Sciences, 21(5), 2483-2495. 10.5194/hess-21-2483-2017

T11. van den Hurk, B.J.J., P. Viterbo, Anton Beljaars, A. Betts, c : Offline validation of the ERA40 surface scheme. ECMWF Technical Memoranda, Technical memorandum, ECMWF.

T12. Viterbo, P., \& Beljaars, A. (1995). An improved landsurface parameterization scheme in the ECMWF model and its validation. Journal of Climate, 8(11), 2716-2748. 10.1175/ 1520-0442(1995)008<2716:AILSPS>2.0.CO;2

T13. Viterbo, P., Beljaars, A., Mahfouf, J., \& Teixeira, J. (1999). The representation of soil moisture freezing and its impact on the stable boundary layer. Quarterly Journal of the Royal Meteorological Society, 125(559, A), 2401-2426. 10.1256/smsqj.55903

Acknowledgments The authors are grateful to all the model developers in reporting on their models in the building of the tables in the Appendix: Elena Shevliakova (GFDL, USA), Philippe Peylin (LSCE, France), Katherine Calvin (PNNL, USA), Gianpaulo Balsamo (ECMWF, UK), Aaron Boone (Meteo France).

\section{Declarations}

Conflict of Interest On behalf of all the authors, the corresponding author states that there is no conflict of interest.

Open Access This article is licensed under a Creative Commons Attribution 4.0 International License, which permits use, sharing, adaptation, distribution and reproduction in any medium or format, as long as you give appropriate credit to the original author(s) and the source, provide a link to the Creative Commons licence, and indicate if changes were made. The images or other third party material in this article are included in the article's Creative Commons licence, unless indicated otherwise in a credit line to the material. If material is not included in the article's Creative Commons licence and your intended use is not permitted by statutory regulation or exceeds the permitted use, you will need to obtain permission directly from the copyright holder. To view a copy of this licence, visit http://creativecommons.org/licenses/by/4.0/.

\section{References}

1. Alexander P, Rabin S, Anthoni P, Henry R, Pugh TAM, Rounsevell MDA, et al. Adaptation of global land use and management intensity to changes in climate and atmospheric carbon dioxide. Glob Chang Biol. 2018;24(7):2791-809. https://doi.org/ 10.1111/gcb.14110.

2. Anderson JD. Ludwig Prandtl's boundary layer. Phys Today. 2005;58(12):42-8. https://doi.org/10.1063/1.2169443.

3. Arino O, Bicheron P, Achard F, Latham J, Witt R, Weber J-L. GLOBCOVER The most detailed portrait of Earth. ESA Bull Eur Space Agency. 2008;136:24-31.

4. Arora VK, Boer GJ. Fire as an interactive component of dynamic vegetation models. J Geophys Res Biogeosci. 2005;110(G2). https://doi.org/10.1029/2005JG000042.

5. Arora VK, Melton JR, Plummer D. An assessment of natural methane fluxes simulated by the CLASS-CTEM model. Biogeosciences. 2018;15(15):4683-709. https://doi.org/10.5194/ bg-15-4683-2018.

6. Avis, C. A. (2012). Simulating the present-day and future distribution of permafrost in the UVic Earth System Climate Model [Thesis]. https://dspace.library.uvic.ca//handle/1828/4030

7. Ball, J. T., Woodrow, I. E., \& Berry, J. A. (1987). A model predicting stomatal conductance and its contribution to the control of photosynthesis under different environmental conditions. In J. Biggins (Ed.), Progress in Photosynthesis Research: Volume 4 Proceedings of the VIIth International Congress on Photosynthesis Providence, Rhode Island, USA, August 10-15, 1986 (pp. 221-224). Springer Netherlands. https://doi.org/10. 1007/978-94-017-0519-6_48

8. Bellassen V, Le Maire G, Dhôte JF, Ciais P, Viovy N. Modelling forest management within a global vegetation model-Part 1: model structure and general behaviour. Ecol Model. 2010;221(20):2458-74. https://doi.org/10.1016/j.ecolmodel. 2010.07.008.

9. Best MJ, Pryor M, Clark DB, Rooney GG, Essery RLH, Menard $\mathrm{CB}$, et al. The Joint UK Land Environment Simulator (JULES), model description-Part 1: energy and water fluxes. Geosci Model Dev. 2011;4(3):677-99. https://doi.org/10.5194/gmd-4677-2011.

10. Betts R. Offset of the potential carbon sink from boreal forestation by decreases in surface albedo. Nature. 2000;408(6809):187-90. https://doi.org/10.1038/35041545.

11. Beven KJ, Kirkby MJ. A physically based, variable contributing area model of basin hydrology / Un modèle à base physique de zone d'appel variable de l'hydrologie du bassin versant. Hydrol Sci Bull. 1979;24(1):43-69. https://doi.org/10.1080/ 02626667909491834 .

12. Bonan GB, Lawrence PJ, Oleson KW, Levis S, Jung M, Reichstein M, Lawrence DM, \& Swenson SC (2011). Improving canopy processes in the Community Land Model version 4 (CLM4) using global flux fields empirically inferred from FLUXNET data. J Geophysical Res: Biogeosciences, 116. https:// doi.org/10.1029/2010JG001593

13. Bonan GB, Patton EG, Harman IN, Oleson KW, Finnigan JJ, Lu Y, et al. Modeling canopy-induced turbulence in the Earth system: a unified parameterization of turbulent exchange within plant canopies and the roughness sublayer (CLM-ml v0). Geosci Model Dev. 2018;11(4):1467-96. https://doi.org/10.5194/gmd-11-14672018.

14. Bonan GB, Williams M, Fisher RA, Oleson KW. Modeling stomatal conductance in the earth system: linking leaf water-use efficiency and water transport along the soil-plant-atmosphere continuum. Geosci Model Dev. 2014;7(5):2193-222. https://doi.org/ 10.5194/gmd-7-2193-2014. 
15. Bondeau A, Smith PC, Zaehle S, Schaphoff S, Lucht W, Cramer $\mathrm{W}$, et al. Modelling the role of agriculture for the 20th century global terrestrial carbon balance. Glob Chang Biol. 2007;13(3): 679-706. https://doi.org/10.1111/j.1365-2486.2006.01305.x.

16. Boysen LR, Brovkin V, Arora VK, Cadule P, de Noblet-Ducoudré $\mathrm{N}$, Kato E, et al. Global and regional effects of land-use change on climate in 21st century simulations with interactive carbon cycle. Earth Syst Dyn. 2014;5(2):309-19. https://doi.org/10.5194/esd-5309-2014.

17. Brovkin V, Boysen L, Raddatz T, Gayler V, Loew A, Claussen M. Evaluation of vegetation cover and land-surface albedo in MPIESM CMIP5 simulations. J Adv Model Earth Syst. 2013;5(1):48 57. https://doi.org/10.1029/2012MS000169.

18. Bussi G, Whitehead PG, Bowes MJ, Read DS, Prudhomme C, Dadson SJ. Impacts of climate change, land-use change and phosphorus reduction on phytoplankton in the River Thames (UK). Sci Total Environ. 2016;572:1507-19. https://doi.org/10.1016/j. scitotenv.2016.02.109.

19. Clark MP, Nijssen B, Lundquist JD, Kavetski D, Rupp DE, Woods RA, et al. A unified approach for process-based hydrologic modeling: 1. Modeling concept. Water Resour Res. 2015;51(4): 2498-514. https://doi.org/10.1002/2015WR017198.

20. Collatz G, Ribas-Carbo M, Berry J. Coupled photosynthesisstomatal conductance model for leaves of C4 plants photosynthesis-stomatal conductance model for leaves of $\mathrm{C} 4$ plants. Aust J Plant Physiol. 1992;19(5):519-38. https://doi.org/ 10.1071/PP9920519.

21. Collins WJ, Bellouin N, Doutriaux-Boucher M, Gedney N, Halloran P, Hinton T, et al. Development and evaluation of an Earth-System model - HadGEM2. Geosci Model Dev. 2011;4(4): 1051-75. https://doi.org/10.5194/gmd-4-1051-2011.

22. Comyn-Platt E, Hayman G, Huntingford C, Chadburn SE, Burke EJ, Harper AB, et al. Carbon budgets for 1.5 and 2 degrees $\mathrm{C}$ targets lowered by natural wetland and permafrost feedbacks. Nat Geosci. 2018;11(8):568. https://doi.org/10.1038/s41561018-0174-9.

23. Cramer W, Bondeau A, Woodward FI, Prentice IC, Betts RA, Brovkin V, et al. Global response of terrestrial ecosystem structure and function to $\mathrm{CO} 2$ and climate change: results from six dynamic global vegetation models. Glob Chang Biol. 2001;7(4):357-73. https://doi.org/10.1046/j.1365-2486.2001.00383.x.

24. Dadson S, Acreman M, Harding R. Water security, global change and land-atmosphere feedbacks. Philos Trans R Soc A Math Phys Eng Sci. 2013;371(2002):20120412. https://doi.org/10.1098/rsta. 2012.0412.

25. Dadson SJ, Garrick DE, Penning-Rowsell EC, Hall JW, Hope R, Hughes J. Water Science. Chichester: Policy and Management; 2019.

26. Dai Y, Dickinson R, Wang Y. A two-big-leaf model for canopy temperature, photosynthesis, and stomatal conductance. J Clim. 2004;17(12):2281-99. https://doi.org/10.1175/1520-0442(2004) 017<2281:ATMFCT>2.0.CO;2.

27. Davin EL, Seneviratne SI, Ciais P, Olioso A, Wang T. Preferential cooling of hot extremes from cropland albedo management. Proc Natl Acad Sci. 2014;111(27):9757-61. https://doi.org/10.1073/ pnas. 1317323111.

28. de Graaf IEM, Gleeson T, van Beek LPHR, Sutanudjaja EH, Bierkens MFP. Environmental flow limits to global groundwater pumping. Nature. 2019;574(7776):90. https://doi.org/10.1038/ s41586-019-1594-4.

29. de Graaf IEM, Sutanudjaja EH, van Beek LPH, Bierkens MFP. A high-resolution global-scale groundwater model. Hydrol Earth Syst Sci. 2015;19(2):823-37. https://doi.org/10.5194/hess-19823-2015.

30. de Graaf IEM, van Beek RLPH, Gleeson T, Moosdorf N, Schmitz $\mathrm{O}$, Sutanudjaja EH, et al. A global-scale two-layer transient groundwater model: development and application to groundwater depletion. Adv Water Resour. 2017;102:53-67. https://doi.org/10. 1016/j.advwatres.2017.01.011.

31. De Kauwe MG, Kala J, Lin Y-S, Pitman AJ, Medlyn BE, Duursma RA, et al. A test of an optimal stomatal conductance scheme within the CABLE land surface model. Geosci Model Dev. 2015;8(2):431-52. https://doi.org/10.5194/gmd-8-4312015.

32. de Noblet-Ducoudré N, Boisier J-P, Pitman A, Bonan GB, Brovkin V, Cruz F, et al. Determining robust impacts of landuse-induced land cover changes on surface climate over North America and Eurasia: Results from the First Set of LUCID Experiments. J Clim. 2012;25(9):3261-81. https://doi.org/10. 1175/JCLI-D-11-00338.1.

33. de Vrese P, Hagemann S. Explicit representation of spatial subgrid-scale heterogeneity in an ESM. J Hydrometeorol. 2016;17(5):1357-71. https://doi.org/10.1175/JHM-D-15-0080.1.

34. de Vrese P, Hagemann S, Claussen M. Asian irrigation, African rain: remote impacts of irrigation. Geophys Res Lett. 2016;43(8): 3737-45. https://doi.org/10.1002/2016GL068146.

35. Decharme $B$, Douville $H$. Introduction of a sub-grid hydrology in the ISBA land surface model. Clim Dyn. 2006;26(1):65-78. https://doi.org/10.1007/s00382-005-0059-7.

36. dePury D, Farquhar G. Simple scaling of photosynthesis from leaves to canopies without the errors of big-leaf models. Plant Cell Environ. 1997;20(5):537-57. https://doi.org/10.1111/j. 1365-3040.1997.00094.x.

37. Dickinson RE, Henderson-Sellers A, Kennedy J, \& Wilson F (1986). Biosphere-atmosphere Transfer Scheme (BATS) for the NCAR Community Climate Model. https://doi.org/10.5065/ D6668B58

38. Dickinson RE, Henderson-Sellers A, \& Kennedy PJ (1993). Biosphere-Atmosphere Transfer Scheme (BATS) version le as coupled to the NCAR community climate model. Technical note. [NCAR (National Center for Atmospheric Research)] (PB-94106150/XAB; NCAR/TN-387+STR). National Center for Atmospheric Research, Boulder, CO (United States). Scientific Computing Div. https://www.osti.gov/biblio/5733868

39. Dolman AJ, Gregory D. The parametrization of rainfall interception In GCMs. Q J R Meteorol Soc. 1992;118(505):455-67. https://doi.org/10.1002/qj.49711850504.

40. Ekici A, Lee H, Lawrence DM, Swenson SC, Prigent C. Ground subsidence effects on simulating dynamic high-latitude surface inundation under permafrost thaw using CLM5. Geosci Model Dev. 2019;12(12):5291-300. https://doi.org/10.5194/gmd-125291-2019.

41. Erb K-H, Kastner T, Plutzar C, Bais ALS, Carvalhais N, Fetzel T, et al. Unexpectedly large impact of forest management and grazing on global vegetation biomass. Nature. 2018;553(7686):73-6. https://doi.org/10.1038/nature25138.

42. Erb K-H, Luyssaert S, Meyfroidt P, Pongratz J, Don A, Kloster S, et al. Land management: data availability and process understanding for global change studies. Glob Chang Biol. 2017;23(2):51233. https://doi.org/10.1111/gcb.13443.

43. Fan, Y., Clark, M., Lawrence, D. M., Swenson, S., Band, L. E., Brantley, S. L., Brooks, P. D., Dietrich, W. E., Flores, A., Grant, G., Kirchner, J. W., Mackay, D. S., McDonnell, J. J., Milly, P. C. D., Sullivan, P. L., Tague, C., Ajami, H., Chaney, N., Hartmann, A., ... Yamazaki, D. (2019). Hillslope hydrology in global change research and earth system modeling. Water Resources Research, 55(2), 1737-1772. https://doi.org/10.1029/2018WR023903

44. Fan Y, Li H, Miguez-Macho G. Global Patterns of groundwater table depth. Science. 2013;339(6122):940-3. https://doi.org/10. 1126/science. 1229881.

45. Faroux S, Tchuente ATK, Roujean J-L, Masson V, Martin E, Le Moigne P. ECOCLIMAP-II/Europe: a twofold database of 
ecosystems and surface parameters at $1 \mathrm{~km}$ resolution based on satellite information for use in land surface, meteorological and climate models. Geosci Model Dev. 2013;6(2):563-82. https:// doi.org/10.5194/gmd-6-563-2013.

46. Farquhar G, Schulze E, Kuppers M. Responses to humidity by stomata of Nicotiana-glauca L and Corylus-avellana L are consistent with the optimization of carbon-dioxide uptake with respect to water-loss. Aust J Plant Physiol. 1980;7(3):315-27. https://doi. org/10.1071/PP9800315.

47. Farthing MW, Ogden FL. Numerical solution of Richards' Equation: a review of advances and challenges. Soil Sci Soc Am J. 2017;81(6):1257-69. https://doi.org/10.2136/sssaj2017.02. 0058 .

48. Feddema J, Oleson K, Bonan G, Mearns L, Washington W, Meehl $\mathrm{G}$, et al. A comparison of a GCM response to historical anthropogenic land cover change and model sensitivity to uncertainty in present-day land cover representations. Clim Dyn. 2005;25(6): 581-609. https://doi.org/10.1007/s00382-005-0038-z.

49. Fisher RA, Koven CD. Perspectives on the future of land surface models and the challenges of representing complex terrestrial systems. J Adv Model Earth Syste. 2020;12(4):e2018MS001453. https://doi.org/10.1029/2018MS001453.

50. Fisher, R. A., Koven, C. D., Anderegg, W. R. L., Christoffersen, B. O., Dietze, M. C., Farrior, C. E., Holm, J. A., Hurtt, G. C., Knox, R. G., Lawrence, P. J., Lichstein, J. W., Longo, M., Matheny, A. M., Medvigy, D., Muller-Landau, H. C., Powell, T. L., Serbin, S. P., Sato, H., Shuman, J. K., ... Moorcroft, P. R. (2018). Vegetation demographics in Earth System Models: a review of progress and priorities. Global Change Biol, 24(1), 35-54. https://doi.org/10.1111/gcb.13910

51. Forkel M, Migliavacca M, Thonicke K, Reichstein M, Schaphoff $\mathrm{S}$, Weber $\mathrm{U}$, et al. Codominant water control on global interannual variability and trends in land surface phenology and greenness. Glob Chang Biol. 2015;21(9):3414-35. https://doi.org/10.1111/ gcb. 12950

52. Franklin, O., Harrison, S. P., Dewar, R., Farrior, C. E., Brännström, Å., Dieckmann, U., Pietsch, S., Falster, D., Cramer, W., Loreau, M., Wang, H., Mäkelä, A., Rebel, K. T., Meron, E., Schymanski, S. J., Rovenskaya, E., Stocker, B. D., Zaehle, S., Manzoni, S., ... Prentice, I. C. (2020). Organizing principles for vegetation dynamics. Nat Plants, 6(5), 444-453. https://doi.org/10.1038/s41477-020-0655-x

53. Franklin O, Johansson J, Dewar RC, Dieckmann U, McMurtrie RE, Brännström $\AA$, et al. Modeling carbon allocation in trees: a search for principles. Tree Physiol. 2012;32(6):648-66. https:// doi.org/10.1093/treephys/tpr138.

54. Friedl M, \& Sulla-Menashe D (2019). MCD12Q1 MODIS/Terra+ Aqua Land Cover Type Yearly L3 Global 500m SIN Grid V006 [Data set]. NASA EOSDIS Land Processes DAAC. 1. https:// lpdaac.usgs.gov/node/ 1260

55. Friedlingstein, P., Jones, M. W., O’Sullivan, M., Andrew, R. M., Hauck, J., Peters, G. P., Peters, W., Pongratz, J., Sitch, S., Le Quere, C., Bakker, D. C. E., Canadell, J. G., Ciais, P., Jackson, R. B., Anthoni, P., Barbero, L., Bastos, A., Bastrikov, V., Becker, M., ... Zaehle, S. (2019). Global Carbon Budget 2019. In Earth System Science Data 11, Issue 4, pp. 1783-1838. https://doi.org/ 10.5194/essd-11-1783-2019

56. Gleick PH, Palaniappan M. Peak water limits to freshwater withdrawal and use. Proc Natl Acad Sci. 2010;107(25):11155-62. https://doi.org/10.1073/pnas.1004812107.

57. Grimmond, C. S. B., Blackett, M., Best, M. J., Baik, J.-J., Belcher, S. E., Beringer, J., Bohnenstengel, S. I., Calmet, I., Chen, F., Coutts, A., Dandou, A., Fortuniak, K., Gouvea, M. L., Hamdi, R., Hendry, M., Kanda, M., Kawai, T., Kawamoto, Y., Kondo, H., ... Zhang, N. (2011). Initial results from Phase 2 of the international urban energy balance model comparison. Int $\mathrm{J}$ Climatol, 31(2), 244-272. https://doi.org/10.1002/joc.2227

58. Guimberteau M, Drapeau G, Ronchail J, Sultan B, Polcher J, Martinez J-M, et al. Discharge simulation in the sub-basins of the Amazon using ORCHIDEE forced by new datasets. Hydrol Earth Syst Sci. 2012;16(3):911-35. https://doi.org/10.5194/hess16-911-2012.

59. Hagerty SB, van Groenigen KJ, Allison SD, Hungate BA, Schwartz E, Koch GW, et al. Accelerated microbial turnover but constant growth efficiency with warming in soil. Nat Clim Chang. 2014;4(10):903-6. https://doi.org/10.1038/nclimate2361.

60. Hanasaki N, Yoshikawa S, Pokhrel Y, Kanae S. A global hydrological simulation to specify the sources of water used by humans. Hydrol Earth Syst Sci. 2018;22(1):789-817. https://doi.org/10. 5194/hess-22-789-2018.

61. Hansen M, Defries R, Townshend J, Sohlberg R. Global land cover classification at $1 \mathrm{~km}$ spatial resolution using a classification tree approach. Int J Remote Sens. 2000;21(6-7):1331-64. https:// doi.org/10.1080/014311600210209.

62. Harper AB, Wiltshire AJ, Cox PM, Friedlingstein P, Jones CD, Mercado LM, et al. Vegetation distribution and terrestrial carbon cycle in a carbon cycle configuration of JULES4.6 with new plant functional types. Geosci Model Dev. 2018;11(7):2857-73. https:// doi.org/10.5194/gmd-11-2857-2018.

63. Hartley AJ, MacBean N, Georgievski G, Bontemps S. Uncertainty in plant functional type distributions and its impact on land surface models. Remote Sens Environ. 2017;203:71-89. https://doi.org/ 10.1016/j.rse.2017.07.037.

64. Haverd V, Smith B, Cook GD, Briggs PR, Nieradzik L, Roxburgh $\mathrm{SH}$, et al. A stand-alone tree demography and landscape structure module for Earth system models. Geophys Res Lett. 2013;40(19): 5234-9. https://doi.org/10.1002/grl.50972.

65. Haverd V, Smith B, Nieradzik L, Briggs PR, Woodgate W, Trudinger CM, et al. A new version of the CABLE land surface model (Subversion revision r4601) incorporating land use and land cover change, woody vegetation demography, and a novel optimisation-based approach to plant coordination of photosynthesis. Geosci Model Dev. 2018;11(7):2995-3026. https://doi. org/10.5194/gmd-11-2995-2018.

66. Henderson-Sellers A, Gornitz V. Possible climatic impacts of land cover transformations, with particular emphasis on tropical deforestation. Clim Chang. 1984;6(3):231-57. https://doi.org/10.1007/ BF00142475.

67. Hurtt GC, Moorcroft PR, Pacala SW, Levin SA. Terrestrial models and global change: challenges for the future. Glob Chang Biol. 1998;4(5):581-90. https://doi.org/10.1046/j.13652486.1998.t01-1-00203.x.

68. Huss M, Hock R. Global-scale hydrological response to future glacier mass loss. Nat Clim Chang. 2018;8(2):135-40. https:// doi.org/10.1038/s41558-017-0049-x.

69. Jarvis PG, Monteith JL, Weatherley PE. The interpretation of the variations in leaf water potential and stomatal conductance found in canopies in the field. Philos Trans R Soc London B, Biol Sci. 1976;273(927):593-610. https://doi.org/10.1098/rstb.1976.0035.

70. Kattge J, Boenisch G, Diaz S, Lavorel S, Prentice IC, Leadley P, et al. TRY plant trait database - enhanced coverage and open access. Glob Chang Biol. 2020;26(1):119-88. https://doi.org/10. 1111/gcb.14904.

71. Kattge, J., Diaz, S., Lavorel, S., Prentice, C., Leadley, P., Boenisch, G., Garnier, E., Westoby, M., Reich, P. B., Wright, I. J., Cornelissen, J. H. C., Violle, C., Harrison, S. P., van Bodegom, P. M., Reichstein, M., Enquist, B. J., Soudzilovskaia, N. A., Ackerly, D. D., Anand, M., ... Wirth, C. (2011). TRY — a global database of plant traits. Glob Chang Biol, 17(9), 2905-2935. https://doi.org/10.1111/j.1365-2486.2011.02451.x 
72. Kattge J, Knorr W. Temperature acclimation in a biochemical model of photosynthesis: a reanalysis of data from 36 species. Plant Cell Environ. 2007;30(9):1176-90. https://doi.org/10.1111/ j.1365-3040.2007.01690.x.

73. Keune J, Gasper F, Goergen K, Hense A, Shrestha P, Sulis M, et al. Studying the influence of groundwater representations on land surface-atmosphere feedbacks during the European heat wave in 2003. J Geophys Res-Atmos. 2016;121(22):13,301-25. https://doi.org/10.1002/2016JD025426.

74. Kirschke, S., Bousquet, P., Ciais, P., Saunois, M., Canadell, J. G., Dlugokencky, E. J., Bergamaschi, P., Bergmann, D., Blake, D. R., Bruhwiler, L., Cameron-Smith, P., Castaldi, S., Chevallier, F., Feng, L., Fraser, A., Heimann, M., Hodson, E. L., Houweling, S., Josse, B., ... Zeng, G. (2013). Three decades of global methane sources and sinks. Nat Geosci, 6(10), 813-823. https://doi.org/10. 1038/NGEO1955

75. Koster RD, Suarez MJ. Modeling the land surface boundary in climate models as a composite of independent vegetation stands. J Geophys Res-Atmos. 1992;97(D3):2697-715. https://doi.org/10. 1029/91JD01696.

76. Kraus D, Weller S, Klatt S, Haas E, Wassmann R, Kiese R, et al. A new LandscapeDNDC biogeochemical module to predict $\mathrm{CH} 4$ and $\mathrm{N} 2 \mathrm{O}$ emissions from lowland rice and upland cropping systems. Plant Soil. 2015;386(1):125-49. https://doi.org/10.1007/ s11104-014-2255-x.

77. Largeron C, Krinner G, Ciais P, Brutel-Vuilmet C. Implementing northern peatlands in a global land surface model: description and evaluation in the ORCHIDEE high-latitude version model (ORCHL-PEAT). Geosci Model Dev. 2018;11(8):3279-97. https://doi. org/10.5194/gmd-11-3279-2018.

78. Lawrence, D. M., Fisher, R. A., Koven, C. D., Oleson, K. W., Swenson, S. C., Bonan, G., Collier, N., Ghimire, B., van Kampenhout, L., Kennedy, D., Kluzek, E., Lawrence, P. J., Li, F., Li, H., Lombardozzi, D., Riley, W. J., Sacks, W. J., Shi, M., Vertenstein, M., ... Zeng, X. (2019). The Community Land Model Version 5: description of new features, benchmarking, and impact of forcing uncertainty. J Adv Model Earth Syst, 11(12), 4245-4287. https://doi.org/10.1029/2018MS001583

79. Lawrence DM, Koven CD, Swenson SC, Riley WJ, Slater AG. Permafrost thaw and resulting soil moisture changes regulate projected high-latitude $\mathrm{CO} 2$ and $\mathrm{CH} 4$ emissions. Environ Res Lett. 2015;10(9):094011. https://doi.org/10.1088/1748-9326/10/ 9/094011.

80. Lawrence DM, Slater AG. Incorporating organic soil into a global climate model. Clim Dyn. 2008;30(2-3):145-60. https://doi.org/ 10.1007/s00382-007-0278-1.

81. Lawrence DM, Slater AG. The contribution of snow condition trends to future ground climate. Clim Dyn. 2010;34(7-8):96981. https://doi.org/10.1007/s00382-009-0537-4.

82. Lee H, Swenson SC, Slater AG, Lawrence DM. Effects of excess ground ice on projections of permafrost in a warming climate. Environ Res Lett. 2014;9(12):124006. https://doi.org/10.1088/ 1748-9326/9/12/124006

83. Leuning R. A critical appraisal of a combined stomatalphotosynthesis model for C3 plants. Plant Cell Environ. 1995;18(4):339-55. https://doi.org/10.1111/j.1365-3040.1995. tb00370.x.

84. Liang X, Lettenmaier DP, Wood EF, Burges SJ. A simple hydrologically based model of land surface water and energy fluxes for general circulation models. J Geophys Res-Atmos. 1994;99(D7): 14415-28. https://doi.org/10.1029/94JD00483.

85. Lombardozzi DL, Bonan GB, Smith NG, Dukes JS, \& Fisher RA (2015). Temperature acclimation of photosynthesis and respiration: a key uncertainty in the carbon cycle-climate feedback. In Geophysical Res Lett 42 20:8624-8631). https://doi.org/10.1002/ 2015GL065934
86. Lombardozzi DL, Lu Y, Lawrence PJ, Lawrence DM, Swenson S, Oleson KW, et al. Simulating agriculture in the community land model Version 5. J Geophys Res Biogeosci. 2020;125(8): e2019JG005529. https://doi.org/10.1029/2019JG005529.

87. Loveland T, Reed B, Brown J, Ohlen D, Zhu Z, Yang L, et al Development of a global land cover characteristics database and IGBP DISCover from $1 \mathrm{~km}$ AVHRR data. Int J Remote Sens. 2000;21(6-7):1303-30. https://doi.org/10.1080/ 014311600210191.

88. Luyssaert S, Jammet M, Stoy PC, Estel S, Pongratz J, Ceschia E, et al. Land management and land-cover change have impacts of similar magnitude on surface temperature. Nat Clim Chang. 2014;4(5):389-93. https://doi.org/10.1038/nclimate2196.

89. Ma Y, Liu H. An advanced multiple-layer canopy model in the WRF model with large-Eddy simulations to simulate canopy flows and scalar transport under different stability conditions. J Adv Model Earth Syst. 2019;11(7):2330-51. https://doi.org/10. 1029/2018MS001347.

90. Martínez-de la Torre A, Miguez-Macho G. Groundwater influence on soil moisture memory and land-atmosphere fluxes in the Iberian Peninsula. Hydrol Earth Syst Sci. 2019;23(12):4909 32. https://doi.org/10.5194/hess-23-4909-2019.

91. Maxwell RM, Condon LE. Connections between groundwater flow and transpiration partitioning. Science. 2016;353(6297): 377-80. https://doi.org/10.1126/science.aaf7891.

92. McDermid SS, Mearns LO, Ruane AC. Representing agriculture in Earth System Models: approaches and priorities for development. J Adv Model Earth Syst. 2017;9(5):2230-65. https://doi. org/10.1002/2016MS000749.

93. Medlyn BE, Duursma RA, Eamus D, Ellsworth DS, Prentice IC, Barton CVM, et al. Reconciling the optimal and empirical approaches to modelling stomatal conductance. Glob Chang Biol. 2011;17(6):2134-44. https://doi.org/10.1111/j.1365-2486.2010. 02375.x.

94. Melton JR, Wania R, Hodson EL, Poulter B, Ringeval B, Spahni $\mathrm{R}$, et al. Present state of global wetland extent and wetland methane modelling: conclusions from a model inter-comparison project (WETCHIMP). Biogeosciences. 2013;10(2):753-88. https://doi. org/10.5194/bg-10-753-2013.

95. Melton JR, Sospedra-Alfonso R, McCusker KE. Tiling soil textures for terrestrial ecosystem modelling via clustering analysis: a case study with CLASS-CTEM (version 2.1). Geosci Model Dev. 2017;10(7):2761-83. https://doi.org/10.5194/gmd-10-2761-2017.

96. Mercado LM, Bellouin N, Sitch S, Boucher O, Huntingford C, Wild $\mathrm{M}$, et al. Impact of changes in diffuse radiation on the global land carbon sink. Nature. 2009;458(7241):1014-U87. https://doi. org/10.1038/nature07949.

97. Mercado LM, Medlyn BE, Huntingford C, Oliver RJ, Clark DB, Sitch $\mathrm{S}$, et al. Large sensitivity in land carbon storage due to geographical and temporal variation in the thermal response of photosynthetic capacity. New Phytol. 2018;218(4):1462-77. https://doi.org/10.1111/nph.15100.

98. Miura Y, Yoshimura K. Development and Verification of a threedimensional variably saturated flow model for assessment of future global water resources. J Adv Model Earth Syst. 2020;12(8): e2020MS002093. https://doi.org/10.1029/2020MS002093.

99. Moore RJ. The PDM rainfall-runoff model. Hydrol Earth Syst Sci. 2007;11(1):483-99. https://doi.org/10.5194/hess-11-483-2007.

100. Nabel JEMS, Naudts K, Pongratz J. Accounting for forest age in the tile-based dynamic global vegetation model JSBACH4 (4.20p7; git feature/forests) - a land surface model for the ICON-ESM. Geosci Model Dev. 2020;13(1):185-200. https:// doi.org/10.5194/gmd-13-185-2020.

101. Nitta T, Yoshimura K, Abe-Ouchi A. Impact of arctic wetlands on the climate system: model sensitivity simulations with the MIROC5 AGCM and a snow-fed wetland scheme. J 
Hydrometeorol. 2017;18(11):2923-36. https://doi.org/10.1175/ JHM-D-16-0105.1.

102. Oki T, Sud YC. Design of Total Runoff Integrating Pathways (TRIP) - a global river channel network. Earth Interact. 1998;2(1):1-37. https://doi.org/10.1175/1087-3562(1998) 002<0001:DOTRIP>2.3.CO; 2 .

103. Olefeldt D, Goswami S, Grosse G, Hayes D, Hugelius G, Kuhry P, et al. Circumpolar distribution and carbon storage of thermokarst landscapes. Nat Commun. 2016;7(1):13043. https://doi.org/10. 1038/ncomms 13043

104. Oliver RJ, Mercado LM, Sitch S, Simpson D, Medlyn BE, Lin Y$\mathrm{S}$, et al. Large but decreasing effect of ozone on the European carbon sink. Biogeosciences. 2018;15(13):4245-69. https://doi. org/10.5194/bg-15-4245-2018.

105. O'Neill HB, Wolfe SA, Duchesne C. New ground ice maps for Canada using a paleogeographic modelling approach. Cryosphere. 2019;13(3):753-73. https://doi.org/10.5194/tc-13-753-2019.

106. Peng B, Guan K, Chen M, Lawrence DM, Pokhrel Y, Suyker A, et al. Improving maize growth processes in the community land model: implementation and evaluation. Agric For Meteorol. 2018;250-251:64-89. https://doi.org/10.1016/j.agrformet.2017. 11.012 .

107. Peng, B., Guan, K., Tang, J., Ainsworth, E. A., Asseng, S., Bernacchi, C. J., Cooper, M., Delucia, E. H., Elliott, J. W., Ewert, F., Grant, R. F., Gustafson, D. I., Hammer, G. L., Jin, Z., Jones, J. W., Kimm, H., Lawrence, D. M., Li, Y., Lombardozzi, D. L., ... Zhou, W. (2020). Towards a multiscale crop modelling framework for climate change adaptation assessment. Nat Plants, 6(4), 338-348. https://doi.org/10.1038/s41477-020-0625-3

108. Piao S, Liu Q, Chen A, Janssens IA, Fu Y, Dai J, et al. Plant phenology and global climate change: current progresses and challenges. Glob Chang Biol. 2019;25(6):1922-40. https://doi.org/10. $1111 / \mathrm{gcb} .14619$.

109. Pitman AJ. The evolution of, and revolution in, land surface schemes designed for climate models. Int J Climatol. 2003;23(5):479-510. https://doi.org/10.1002/joc.893.

110. Pitman AJ, Henderson-Sellers A, Yang Z-L. Sensitivity of regional climates to localized precipitation in global models. Nature. 1990;346(6286):734-7. https://doi.org/10.1038/346734a0.

111. Polgar CA, Primack RB. Leaf-out phenology of temperate woody plants: from trees to ecosystems. New Phytol. 2011;191(4):92641. https://doi.org/10.1111/j.1469-8137.2011.03803.x.

112. Pongratz J, Dolman H, Don A, Erb K-H, Fuchs R, Herold M, et al. Models meet data: challenges and opportunities in implementing land management in Earth system models. Glob Chang Biol. 2018;24(4):1470-87. https://doi.org/10.1111/gcb.13988.

113. Pongratz J, Reick CH, Raddatz T, Claussen M. Biogeophysical versus biogeochemical climate response to historical anthropogenic land cover change. Geophys Res Lett. 2010;37(8). https://doi. org/10.1029/2010GL043010.

114. Poulter B, Frank DC, Hodson EL, Zimmermann NE. Impacts of land cover and climate data selection on understanding terrestrial carbon dynamics and the $\mathrm{CO} 2$ airborne fraction. Biogeosciences. 2011;8(8):2027-36. https://doi.org/10.5194/bg-8-2027-2011.

115. Pugh TAM, Arneth A, Olin S, Ahlström A, Bayer AD, Goldewijk KK, et al. Simulated carbon emissions from land-use change are substantially enhanced by accounting for agricultural management. Environ Res Lett. 2015;10(12):124008. https://doi.org/10. 1088/1748-9326/10/12/124008.

116. Quaife T, Quegan S, Disney M, Lewis P, Lomas M, Woodward FI. Impact of land cover uncertainties on estimates of biospheric carbon fluxes. Glob Biogeochem Cycles. 2008;22(4). https://doi. org/10.1029/2007GB003097.

117. Richards LA. Capillary conduction of liquids through porous mediums-NASA/ADS. Physics. 1931;1(5):318-33. https://doi.org/ 10.1063/1.1745010.
118. Riley WJ, Subin ZM, Lawrence DM, Swenson SC, Torn MS, Meng L, et al. Barriers to predicting changes in global terrestrial methane fluxes: analyses using CLM4Me, a methane biogeochemistry model integrated in CESM. Biogeosciences. 2011;8(7):1925-53. https://doi.org/10.5194/bg-8-1925-2011.

119. Sabot MEB, Kauwe MGD, Pitman AJ, Medlyn BE, Verhoef A, Ukkola AM, et al. Plant profit maximization improves predictions of European forest responses to drought. New Phytol. 2020;226(6):1638-55. https://doi.org/10.1111/nph.16376.

120. Sacks WJ, Cook BI, Buenning N, Levis S, Helkowski JH. Effects of global irrigation on the near-surface climate. Clim Dyn. 2009;33(2):159-75. https://doi.org/10.1007/s00382-008-0445-z.

121. Schultz NM, Lee X, Lawrence PJ, Lawrence DM, Zhao L. Assessing the use of subgrid land model output to study impacts of land cover change. J Geophys Res-Atmos. 2016;121(11): 6133-47. https://doi.org/10.1002/2016JD025094.

122. Sellers PJ, Mintz Y, Sud YC, Dalcher A. A simple biosphere model (SIB) for use within general circulation models. J Atmos Sci. 1986;43(6):505-31. https://doi.org/10.1175/15200469(1986)043<0505:ASBMFU>2.0.CO;2.

123. Sellers PJ, Randall D, Collatz G, Berry J, Field C, Dazlich D, et al. A revised land surface parameterization $(\mathrm{SiB} 2)$ for atmospheric GCMs .1. Model formulation. J Clim. 1996;9(4):676-705. https://doi.org/10.1175/1520-0442(1996)009<0676:ARLSPF $>2$. $0 . \mathrm{CO} ; 2$.

124. Shevliakova, E., Pacala, S. W., Malyshev, S., Hurtt, G. C., Milly, P. C. D., Caspersen, J. P., Sentman, L. T., Fisk, J. P., Wirth, C., \& Crevoisier, C. (2009). Carbon cycling under 300 years of land use change: importance of the secondary vegetation sink. Global Biogeochem Cycles, 23. https://doi.org/10.1029/2007GB003176

125. Sitch S, Smith B, Prentice IC, Arneth A, Bondeau A, Cramer W, et al. Evaluation of ecosystem dynamics, plant geography and terrestrial carbon cycling in the LPJ dynamic global vegetation model. Glob Chang Biol. 2003;9(2):161-85. https://doi.org/10. 1046/j.1365-2486.2003.00569.x.

126. Smith NG, Malyshev SL, Shevliakova E, Kattge J, Dukes JS. Foliar temperature acclimation reduces simulated carbon sensitivity to climate. Nat Clim Chang. 2016;6(4):407-11. https://doi.org/ 10.1038/nclimate2878.

127. Sperry JS, Venturas MD, Anderegg WRL, Mencuccini M, Mackay DS, Wang Y, et al. Predicting stomatal responses to the environment from the optimization of photosynthetic gain and hydraulic cost. Plant Cell Environ. 2017;40(6):816-30. https:// doi.org/10.1111/pce.12852.

128. Tang X, Pei X, Lei N, Luo X, Liu L, Shi L, et al. Global patterns of soil autotrophic respiration and its relation to climate, soil and vegetation characteristics. Geoderma. 2020;369:114339. https:// doi.org/10.1016/j.geoderma.2020.114339.

129. Thiery W, Visser AJ, Fischer EM, Hauser M, Hirsch AL, Lawrence DM, et al. Warming of hot extremes alleviated by expanding irrigation. Nat Commun. 2020;11(1):290. https://doi. org/10.1038/s41467-019-14075-4.

130. Thornton PE, Calvin K, Jones AD, Di Vittorio AV, BondLamberty B, Chini L, et al. Biospheric feedback effects in a synchronously coupled model of human and Earth systems. Nat Clim Chang. 2017;7(7):496-500. https://doi.org/10.1038/ nclimate3310.

131. Todd-Brown KEO, Randerson JT, Hopkins F, Arora V, Hajima T, Jones $\mathrm{C}$, et al. Changes in soil organic carbon storage predicted by Earth system models during the 21 st century. Biogeosciences. 2014;11(8):2341-56. https://doi.org/10.5194/bg-11-2341-2014.

132. Todini E. The ARNO rainfall-runoff model. J Hydrol. 1996;175(1):339-82. https://doi.org/10.1016/S0022-1694(96) 80016-3.

133. Tuinenburg OA, Hutjes RWA, Stacke T, Wiltshire A, LucasPicher P. Effects of irrigation in India on the atmospheric water 
budget. J Hydrometeorol. 2014;15(3):1028-50. https://doi.org/10. 1175/JHM-D-13-078.1.

134. Turetsky MR, Abbott BW, Jones MC, Anthony KW, Olefeldt D, Schuur EAG, et al. Carbon release through abrupt permafrost thaw. Nat Geosci. 2020;13(2):138-43. https://doi.org/10.1038/ s41561-019-0526-0.

135. Verhoef A, Bruin D, H. a. R., \& Van Den Hurk, B. J. J. M. Some practical notes on the Parameter $\mathrm{kB}-1$ for Sparse Vegetation. J Appl Meteorol. 1997;36(5):560-72. https://doi.org/10.1175/ 1520-0450(1997)036<0560:SPNOTP>2.0.CO;2.

136. Verseghy DL, McFarlane NA, Lazare M. CLASS - a Canadian land surface scheme for GCMS, II. Vegetation model and coupled runs. Int J Climatol. 1993;13(4):347-70. https://doi.org/10.1002/ joc. 3370130402 .

137. Walker TWN, Kaiser C, Strasser F, Herbold CW, Leblans NIW, Woebken D, et al. Microbial temperature sensitivity and biomass change explain soil carbon loss with warming. Nat Clim Chang. 2018;8(10):885-9. https://doi.org/10.1038/s41558-018-0259-x.

138. Wang P-L, Feddema JJ. Linking global land use/land cover to hydrologic soil groups from 850 to 2015. Glob Biogeochem Cycles. 2020;34(3):e2019GB006356. https://doi.org/10.1029/ 2019GB006356.

139. Wang Y, Leuning R. A two-leaf model for canopy conductance, photosynthesis and partitioning of available energy I: model description and comparison with a multi-layered model. Agric For Meteorol. 1998;91(1-2):89-111. https://doi.org/10.1016/S01681923(98)00061-6.

140. Wang YP, Houlton BZ, Field CB. A model of biogeochemical cycles of carbon, nitrogen, and phosphorus including symbiotic nitrogen fixation and phosphatase production. Glob Biogeochem Cycles. 2007;21(1). https://doi.org/10.1029/2006GB002797.

141. Wang YP, Lu XJ, Wright IJ, Dai YJ, Rayner PJ, Reich PB. Correlations among leaf traits provide a significant constraint on the estimate of global gross primary production. Geophys Res Lett. 2012;39:19405. https://doi.org/10.1029/2012GL053461.

142. Watanabe S, Hajima T, Sudo K, Nagashima T, Takemura T, Okajima H, et al. MIROC-ESM 2010: Model description and basic results of CMIP5-20c3m experiments. Geosci Model Dev. 2011;4(4):845-72. https://doi.org/10.5194/gmd-4-845-2011.

143. Weng ES, Malyshev S, Lichstein JW, Farrior CE, Dybzinski R, Zhang $\mathrm{T}$, et al. Scaling from individual trees to forests in an Earth system modeling framework using a mathematically tractable model of height-structured competition. Biogeosciences. 2015;12(9):2655-94. https://doi.org/10.5194/bg-12-2655-2015.

144. Westermann S, Langer M, Boike J, Heikenfeld M, Peter M, Etzelmüller B, et al. Simulating the thermal regime and thaw processes of ice-rich permafrost ground with the land-surface model CryoGrid 3. Geosci Model Dev. 2016;9(2):523-46. https://doi.org/10.5194/gmd-9-523-2016.

145. White MA, Thornton PE, Running SW. A continental phenology model for monitoring vegetation responses to interannual climatic variability. Glob Biogeochem Cycles. 1997;11(2):217-34. https:// doi.org/10.1029/97GB00330.

146. Wieder WR, Allison SD, Davidson EA, Georgiou K, Hararuk O, $\mathrm{He} \mathrm{Y}$, et al. Explicitly representing soil microbial processes in Earth system models. Glob Biogeochem Cycles. 2015;29(10): 1782-800. https://doi.org/10.1002/2015GB005188.

147. Wik M, Varner RK, Anthony KW, MacIntyre S, Bastviken D. Climate-sensitive northern lakes and ponds are critical components of methane release. Nat Geosci. 2016;9(2):99. https://doi. org/10.1038/NGEO2578.

148. Winckler J, Lejeune Q, Reick CH, Pongratz J. Nonlocal effects dominate the global mean surface temperature response to the biogeophysical effects of deforestation. Geophys Res Lett. 2019;46(2):745-55. https://doi.org/10.1029/2018GL080211.

149. Winkler AJ, Myneni RB, Alexandrov GA, Brovkin V. Earth system models underestimate carbon fixation by plants in the high latitudes. Nat Commun. 2019;10(1):885. https://doi.org/10.1038/ s41467-019-08633-z.

150. Wolf A, Anderegg WRL, Pacala SW. Optimal stomatal behavior with competition for water and risk of hydraulic impairment. Proc Natl Acad Sci. 2016;113(46):E7222-30. https://doi.org/10.1073/ pnas. 1615144113.

151. Yokohata T, Kinoshita T, Sakurai G, Pokhrel Y, Ito A, Okada M, et al. MIROC-INTEG1: a global bio-geochemical land surface model with human water management, crop growth, and landuse change. Geosci Model Dev Discuss. 2019;13:4713-47. 157. https://doi.org/10.5194/gmd-2019-184.

152. Zaehle S, Ciais P, Friend AD, Prieur V. Carbon benefits of anthropogenic reactive nitrogen offset by nitrous oxide emissions. Nat Geosci. 2011;4(9):601-5. https://doi.org/10.1038/ngeo1207.

153. Zampieri M, Serpetzoglou E, Anagnostou EN, Nikolopoulos EI, Papadopoulos A. Improving the representation of rivergroundwater interactions in land surface modeling at the regional scale: observational evidence and parameterization applied in the Community Land Model. J Hydrol. 2012;420-421:72-86. https:// doi.org/10.1016/j.jhydrol.2011.11.041.

Publisher's Note Springer Nature remains neutral with regard to jurisdictional claims in published maps and institutional affiliations. 